\title{
Extending the East Asian Miracle: Microeconomic Evidence from Korea
}

Do THE ECONOMIES of East Asia need to undertake fundamental economic reform to resume a path of strong economic growth? This vital question, posed in the wake of the economic crisis of 1997, has divided both economists and policymakers.

The case against major structural reform begins with the dramatic growth of these economies over the past twenty years. For example, Korea, the focus of this paper, has transformed itself into a major economic power, exporting cars and semiconductors to the world and quintupling its GDP per capita between 1970 and 1995. East Asia's achievement is all the more remarkable given that most developing countries have achieved very little development and have fallen further behind the advanced economies. Indeed, East Asia has been used as an example to understand how other countries could achieve more rapid economic development and convergence. ${ }^{1}$

According to those who contend that major reform is unnecessary, the crisis of 1997 was the result of macroeconomic (notably currency) mismanagement and the effects of economic crises in Thailand that created a temporary liquidity shortage. For example, Steven Radelet and Jeffrey Sachs characterize the crisis as a financial panic that shifted the countries involved from a high-investment to a low-investment equilibrium. They argue that "much of the economic activity supported by

The authors would like to thank the participants of the June 1998 meeting for their many helpful comments, and also Jim Bemowski, Cuong Do, Bob Felton, Ted Hall, and Bill Lewis.

1. See, for example, World Bank (1993). 
the capital inflows was highly productive.',2 In short, the case against reform is that the economic fundamentals must be right because growth was so good for so long and a temporary crisis does not make the case for a major course correction.

The case for reform among Western economists has its intellectual origins in the work of Alwyn Young, Jong-Il Kim and Lawrence Lau, and Susan Collins and Barry Bosworth. ${ }^{3}$ Their analyses indicated that the miracle growth of East Asia was primarily caused by rapid capital and labor input growth rather than rapid productivity growth. Although no one forecast a crisis based on this work, the results did suggest that growth was likely to slow unless these economies could base more of their growth on increased productivity. ${ }^{4}$

Like Radelet and Sachs, Paul Krugman and Giancarlo Corsetti, Paolo Pesenti, and Nouriel Roubini point to short-term confidence and liquidity problems in their analyses of the crisis. ${ }^{5}$ But they also stress the rapid investment that has occurred in the affected countries and the declining ratios of output to capital and returns that have accompanied this rapid investment. These falling returns are said to have contributed significantly to the loss of investor confidence and to have combined with the other short-term developments to cause the crisis. The authors attribute continued investment in the face of declining returns to a moral hazard problem involving government-guaranteed lenders lending to uncapitalized but politically connected "'ministers' nephews."

Advocates of reform in East Asia have included those who saw the economic systems at first hand. For example, the current president of Korea, Kim Dae Jung, wrote a book in English in 1985 pointing out

2. Radelet and Sachs (1998, pp. 2, 5). Many observers have suggested that there are moral hazard problems inherent in the lending practices of Asian financial institutions, but Radelet and Sachs are skeptical of their importance. They note that although "many borrowers did have explicit or implicit [loan] guarantees . . . a substantial number of purely private banks and firms without such insurance are now facing bankruptcy.",

3. Young (1994, 1995); Kim and Lau (1994); and Collins and Bosworth (1996).

4. Debates about growth in East Asia often get caught up in the issue of how much credit these countries should get for their economic success. As we will comment later in this paper, we fully recognize that there is no easy mail-order way to increase capital and use it productively. The mobilization of resources in these countries was a major task.

5. Krugman (1998); and Corsetti, Pesenti, and Roubini (1998). 
the problems in the Korean economic system and the need for economic as well as political reform. ${ }^{6}$

In short, the slow growth of total factor productivity in East Asia combined with problems that were widely revealed by the crisis have suggested that reform may be needed-reform of the financial sector as well as more general economic reform. ${ }^{\text {? }}$

This paper uses new evidence to suggest that comprehensive economic reform is essential for the Korean economy to resume sustained rapid economic growth. We do not emphasize such macroeconomic topics as the necessity for liquidity and currency stability, even though these are certainly important. Rather, the focus here is on industrylevel analysis that uncovers structural problems that have limited the growth of total factor productivity, distorted the allocation of capital, reduced the return on capital, and made the economy vulnerable to crisis.

Overwhelmingly, the debate about East Asian growth and the subsequent crisis has been based on macroeconomic data ${ }^{8}$ These data and even conventional industry studies can provide important insights but in the end are likely to be incomplete. This paper will draw on the results of a year-long study of the Korean economy conducted by the McKinsey Global Institute and the Seoul Office of McKinsey \& Company. ${ }^{9}$ The study includes detailed microeconomic case studies of eight

6. Mass Participatory Economy: Korea's Road to World Economic Power was first published in 1985 (Kim Dae Jung, 1996, rev. ed.). This book was written while President Kim was in exile in the United States; Kim was aided by You Jong Keun, then a professor of economics at Rutgers and now governor of Chollabuk-do Province and a principal adviser to the president.

7. The appropriateness of macroeconomic policy in East Asia is an important part of the debate that we will not engage here. The International Monetary Fund argues that high interest rates are essential to restore stability to the currency markets, while critics argue that such high rates are unnecessary and result in severe recession.

8. An exception to this statement is The East Asian Miracle (World Bank, 1993), which does review some industry data and draws on industry case studies by, for example, Pack (1993).

9. This report (McKinsey Global Institute, 1998a) is the source of most of the information in this paper and will not be cited with each statement of fact. The core project team that prepared the report included Taejoon Chin, Dongchun Choi, Sungmi Chung, Jinwook Jung, Dongil Kim, Hyunsoo Kim, Chanjoong Park, Sehun Park, Jaesoo Shim, and Sanghun Yeo from Seoul, with Andrew Gomperts, Alex Schmitz, and Michael Warren from MGI. Yongsung Kim, Seungjoo Lee, and Victoria Nam were the project managers from Seoul, with Eric Zitzewitz from MGI. Vincent Palmade and 
major Korean industries, measuring productivity and identifying the aspects of both the production process and the regulatory environment that cause productivity differences with best practices. The case study approach limits the use of statistical hypothesis testing but offers insights into the causes of productivity differences that are normally unavailable to academic researchers. McKinsey \& Company works with clients in the industries it studies, can observe how establishments operate, and has experts that know each industry worldwide.

This industry-level analysis yields insights that are more difficult to reach using aggregate information. First, we find much stronger evidence of overinvestment than is suggested by aggregate data. Whereas the aggregate Korean capital-labor ratio is only 34 percent of that in the United States, it is $\mathbf{5 7}$ percent in the manufacturing sector, which has better access to domestic and foreign capital. Within manufacturing, we found industries that have reached or exceeded U.S. levels of capital intensity have done so despite having only about 50 percent of U.S. total factor productivity. Low returns in the most indebted part of the economy have been the natural result. Second, moral hazard in lending only partly explains overinvestment. Moral hazard may have affected the incentives of some lenders, but we found many examples of poor investments made by borrowers with substantial equity interest. Korea appears to have suffered from an unfortunate coincidence. It deregulated its capital markets and increased the availability of capital just when overall growth slowed and land price inflation ended, making profitable investment much less automatic. Korean firms did not develop capital management skills quickly enough to cope with this new environment. Other emerging economies that are deregulating their capital markets may face the same problem. Finally, our case studies in services reveal the tangible effects of sector-specific barriers that limit growth and the ability of these industries to absorb workers displaced in manufacturing.

Jaana Remes from MGI contributed to the synthesis and writing the final report. The project was directed by Cuong Do, William Lewis, Jim Bemowski, Robert Felton, and Martin Baily. The outside advisory committee was chaired by Robert Solow, with Richard Cooper, Sangyong Park, and Ted Hall. 
Figure 1. GDP and Total Factor Inputs per Capita, and Total Factor Productivity, United States, Japan, and Korea, 1970-95

GDP per capita ${ }^{a}$

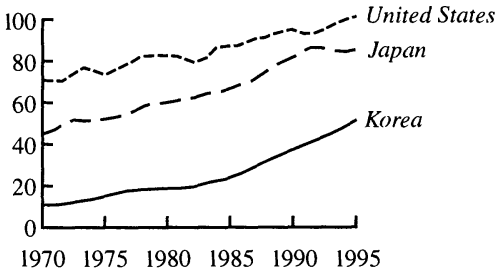

Total factor inputs per capita

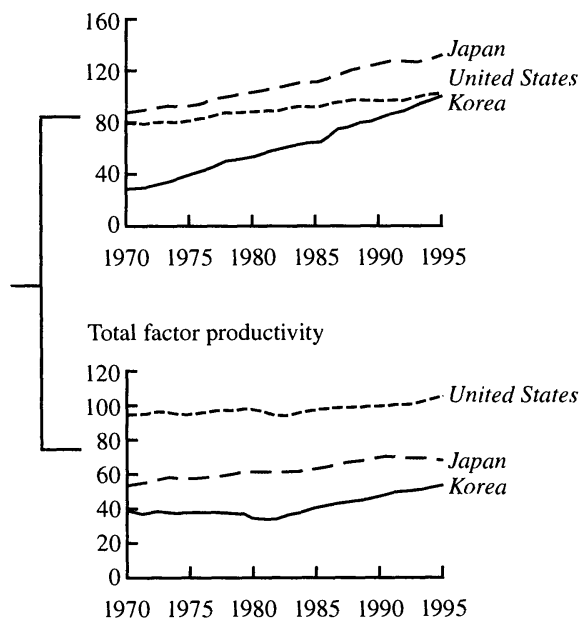

Index: United States $1995=100$

Source: McKinsey Global Institute (1998a, "Aggregate Analysis," p. 1).

a. Excludes residential real estate.

\section{Aggregate Analysis}

Korea has been among the fastest growing economies since 1970 , increasing its GDP per capita fivefold to US\$12,600 in 1995, about half the U.S. level. We carried out our own growth accounting exercise and confirmed that the impressive growth has been largely driven by increases in total factor inputs (figure 1). Input growth accounts for 77 percent of the output growth from 1970 to 1995 , driven by a capital stock that grew at 12 percent a year. Total factor productivity growth accounts for the remaining 23 percent. ${ }^{10} \mathrm{We}$ did not treat increases in

10. Our aggregate capital data are estimated using a perpetual inventory method with sudden death depreciation and standardized asset lives for all countries (forty years for structures, fifteen years for equipment). We developed our own aggregate estimates in order to be consistent with the methodology used in the cases (see the appendix). Our aggregate estimates do not yield significantly different results from those in the literature: we estimate total factor productivity (unadjusted for "labor quality") growth of 3.2 percent in the 1980s versus 3.4 percent in Young (1995). Estimates of TFP levels vary 
years of schooling as input in either our aggregate growth accounting or our cases. We prefer instead to assign all the contributions of intangible capital to increases in total factor productivity-education, technology, and improvements in business systems. In part this reflects skepticism among McKinsey's industry experts about the contribution years of schooling makes to productivity. They do not see a direct connection between much of what is learned in school and what is required on the job. And they observe high-productivity establishments operating despite low education levels, provided there is good training. It is not necessary to agree with this judgment, however. ${ }^{11}$ The speed with which Korea created an educated work force (accounting for years of schooling in the traditional manner) only strengthens the conclusion that growth has been input driven. ${ }^{12}$

Figures 2 and 3 summarize the Korean development path and the level of income the country has reached. The United States, Germany, and France followed a productivity-oriented path, with much higher levels of GDP per capita at each level of inputs. By 1995 Korea and Japan had reached or exceeded the levels of inputs of the three Western economies, but on a flatter, lower productivity path. Korea's GDP per capita of about 50 percent of that in the United States in 1995 was achieved with about the same level of inputs, albeit with a very different mix - more labor and less capital. The overall capital-labor ratio in Korea was 34 percent of the ratio in the United States in 1995.

more, but our estimate of 42 percent for the United States is between the estimates of 34 percent and 58 percent by Pilat (1994) and Hall and Jones (forthcoming), respectively.

11. In a study of Brazil, the average level of education was far below that in the United States, but some establishments with average work forces used U.S.-style business systems and achieved productivity comparable to that in the United States. In Korea we were told that the increase over time in the educational level of the work force was of very limited value in the steel industry. We recognize the weight of evidence linking education to market-determined wages, however, and we believe that some reasonable level of education is required for a modern high-productivity economy-not to mention a democratic society. The econometric evidence linking education to economic growth is sketchier than is often thought, though. For example, Mark Bils and Peter Klenow (1998) have found that growth causes schooling more than the other way around. And Jess Benhabib and Mark Spiegel (1994) found that in a regression of growth on capital, labor, and human capital inputs, the human capital or education variable entered with a coefficient of essentially zero.

12. The shares of the work force with high school and university education increased from 14 percent and 3 percent in 1970 to 44 percent and 19 percent in 1995 according to recent data from the Korean National Statistical Office (Pilat 1994). 
Figure 2. GDP and Labor and Capital Inputs per Capita, Five Countries, to 1995

Per capita GDP

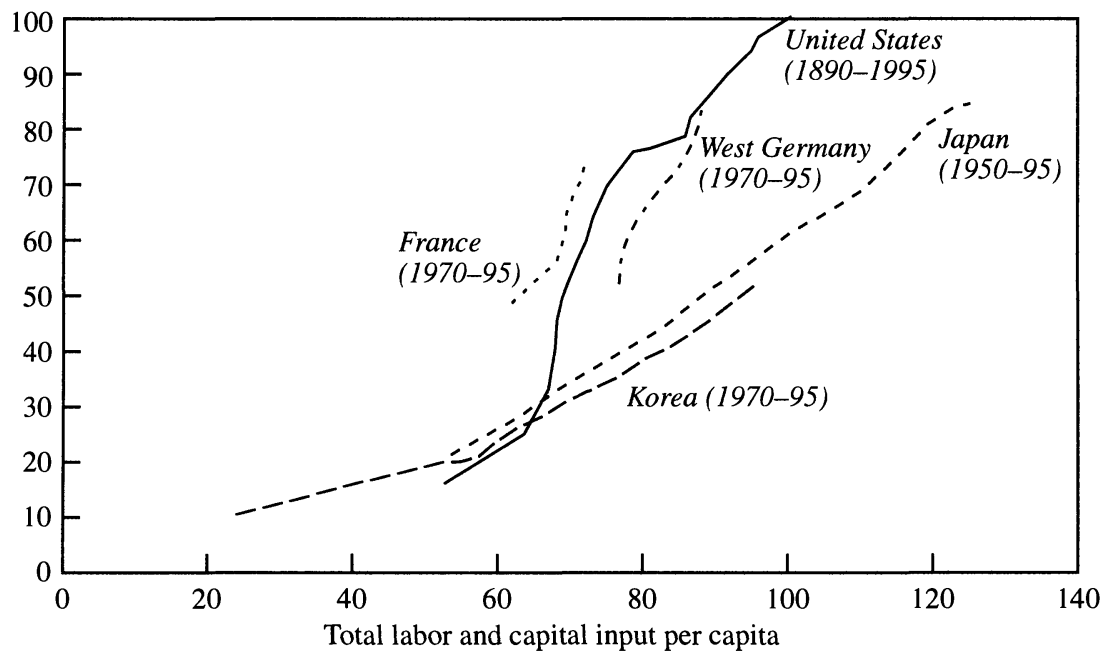

Percent of U.S. 1995 level

Source: McKinsey Global Institute (1998a, “Aggregate Analysis,” p. 6). Residential real estate excluded.

With a capital-labor ratio that is still little more than a third of the U.S. level, it is not obvious that Korea has overinvested or should expect a low rate of return to capital. Aggregate capital productivity (the ratio of output to capital) has declined rapidly in Korea since 1970, but by 1995 it was still 5 percent above the U.S. level. The aggregate rate of return on capital, as measured by the Organization for Economic Cooperation and Development, has fallen from 22 percent to 14 percent between 1984 and 1994, but is still within a percentage point of the average for the European Union. ${ }^{13}$ Signs of trouble emerge, however, when one looks at the sector level. Figure 4 shows how unevenly the capital has been applied. Manufacturing in Korea has absorbed much of the investment and by 1995 had a lower capital-productivity ratio than the United States had. As capital productivity declines, the pool of resources from which to pay returns to capital is squeezed. Using

13. The European Union is used as a comparison because the OECD has stopped publishing figures on rates of return on capital for the United States. The 1994 figure for Japan was about 13 percent. 
Figure 3. Components of GDP per Capita, United States, Japan, and Korea

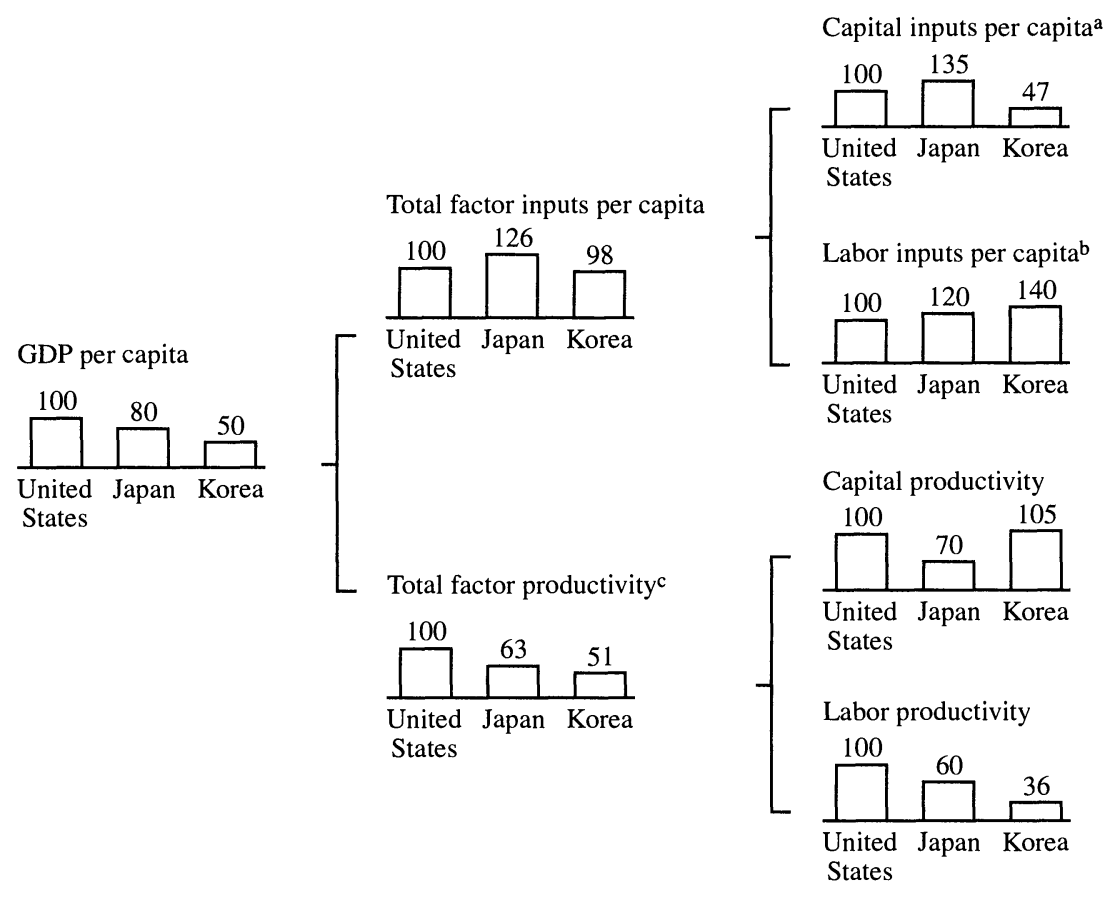

Index: U.S. $1993-95$ average $=100 ; 1995$ U.S. dollars at purchasing power parity

Source: McKinsey Global Institute (1998a, “Aggregate Analysis,” p. 6).

a. Excludes residential real estate in GDP and dwellings in capital stock.

b. Hours worked.

c. Based on Cobb-Douglas production function with labor share of 66 percent.

Bank of Korea data, figure 5 shows the return on invested capital in industrial companies, excluding capital gains on land. Measurement difficulties for such data are acute, but they suggest that returns have been below the cost of debt for most of the period from 1981 to $1995 .{ }^{14}$ Land appreciation may have helped justify investment in manufacturing during the 1980s, but since 1991 land values have been flat or decreasing. The recent profitability of the top thirty chaebol (individual conglomerates in Korea), which are predominantly involved in manufac-

14. The returns and interest cost are in nominal terms and hence could be misleading if inflation is changing. Notice the consistent gap in the United States, however, despite variations in the inflation rate. 
Figure 4. Estimated Components of GDP per Capita for Manufacturing and Services in Korea, 1995

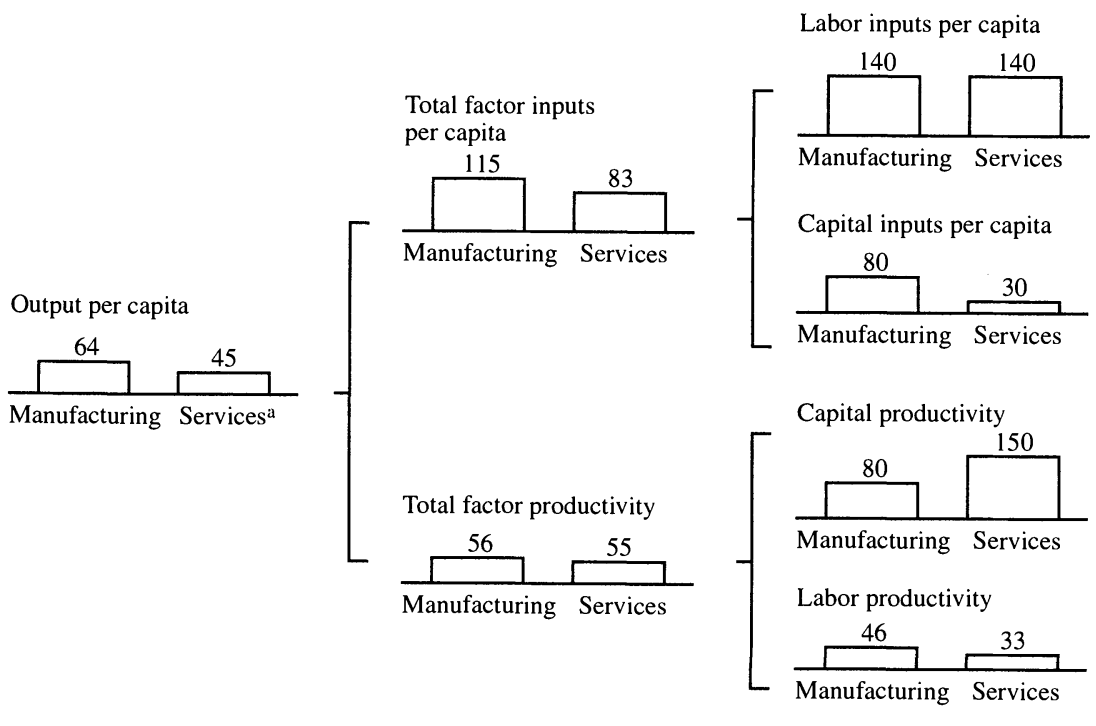

Index: United States in $1995=100$

Source: McKinsey Global Institute (1998, “Synthesis," p. 5).

a. Includes agriculture and construction.

turing, is also below the cost of debt according to Seung Jung Lee. ${ }^{15}$ Manufacturing accounts for 38 percent of the total Korean capital stock; low returns on so large a portion of Korean capital seem consistent with a loss of investor confidence.

The aggregate data whet the appetite for more detail, and we provide this now by reviewing eight case studies, four in manufacturing and four in services and construction.

\section{Manufacturing Cases}

We studied the automotive, food processing, semiconductor, and steel industries in Korea and compared them with those in Japan and the United States. Of these four, two of the industries contain subseg-

15. Lee (1997). 
Figure 5. Return on Invested Capital and Cost of Debt in Industrial Companies, United States, Japan, and Korea, 1981-95

- Pretax ROIC

- - - Pretax cost of debt
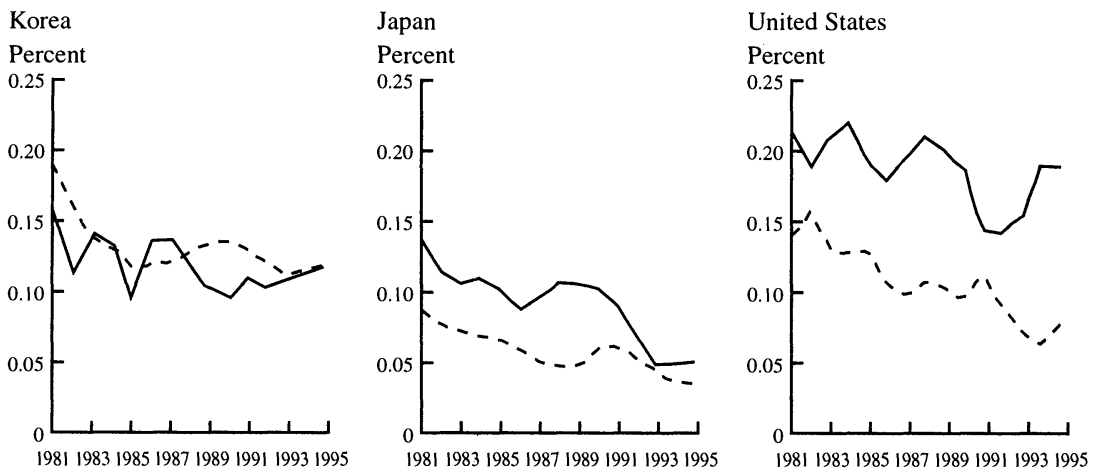

Source: McKinsey Global Institute (1998a, “Aggregate Analysis," p. 9). Land purchases included in invested capital at book value. Land appreciation excluded from earnings. Cost of debt estimated from financial statements (interest expense divided by debt outstanding).

ments that are different enough to merit separate consideration. In food processing, most of the industry has capital intensity levels that are close to those of the United States. In most cases these levels have been reached only very recently: the capital intensity of the whole sector rose from about 30 percent to 72 percent of the U.S. level from 1987 to 1995. Some processed food industries, such as milling, noodles, and preserved fruits and vegetables, never received this investment and remain at less than 50 percent of U.S. capital intensity. In steel, although both the integrated producers and the minimills have high capital intensity, the integrated producers have world class productivity, but the minimills are only 65 percent as productive as minimills in Japan. ${ }^{16}$ In total then, we surveyed six manufacturing industries or subindustries: automotive, semiconductors, high- and low-capital-intensity food processing, integrated steel mills, and minimills.

Of the six, four resemble the manufacturing averages in terms of

16. Integrated steel mills produce steel from iron ore and coking coal in blast furnaces and basic oxygen furnaces, whereas minimills produce steel from scrap steel in electric arc furnaces. Minimills are a newer technology and, as the name suggests, can produce efficiently at much lower scales than integrated facilities (less than 1 million tons as opposed to 5 million to 10 million tons a year). 
Table 1. Capital Productivity and Return on Capital Investments, Selected Industries, Korea, 1995

Index: United States $=100$

\begin{tabular}{lccc}
\hline & Capital intensity $^{\mathbf{a}}$ & Capital productivity & $\begin{array}{c}\text { Rate of return on } \\
\text { capital investments }^{\mathbf{b}}\end{array}$ \\
\hline Semiconductor & 96 & 54 & 64 \\
Automobile & 100 & 48 & 57 \\
Confectionery & 112 & 42 & 50 \\
\hline
\end{tabular}

Source: McKinsey Global Institute (1998a, "Synthesis and implications," p. 22).

a. Capital inputs per labor hour.

b. Production rate of return $=$ capital productivity $\times(P P P$ (output $) \div$ PPP (investment goods $)) \times($ share of capital in value added).

capital intensity and total factor productivity: automotive, semiconductors, high-capital-intensity food processing, and minimills. These industries have near best-practice capital intensity but roughly 50 percent of best-practice productivity and have earned low returns on their capital (table 1).

We discuss these industries first before turning to the two outliers, low-capital-intensity food processing and integrated steel mills. The first four cases help explain the overall result for Korean manufacturing - that investment in best-practice capital intensity has not produced best-practice productivity. The last two cases provide instructive exceptions to this general result.

\section{Automotive}

The automotive industry is still fairly young in Korea. In 1980 the country produced about 100,000 vehicles, mostly from licensed designs and for domestic consumption. By 1996 output had grown to nearly 3 million domestically designed vehicles, about 40 percent of which were exported. During this period capital intensity increased from less than 50 percent of that in the United States in 1985 to the same as that in the United States in 1995. Total factor productivity in Korea has grown 11.5 percent a year since 1985 , but despite high capital intensity it remains less than 50 percent of that in the United States and 40 percent of that in Japan (figure 6). The overall productivity figures are consistent with plant-level data. Korean producers have similar numbers of robots per worker and have automated their stamping, welding, and painting to the same extent as producers in the United States, but hours worked per vehicle are twice as high. 
Figure 6. Automotive Productivity, the United States, Japan, and Korea, 1985-95

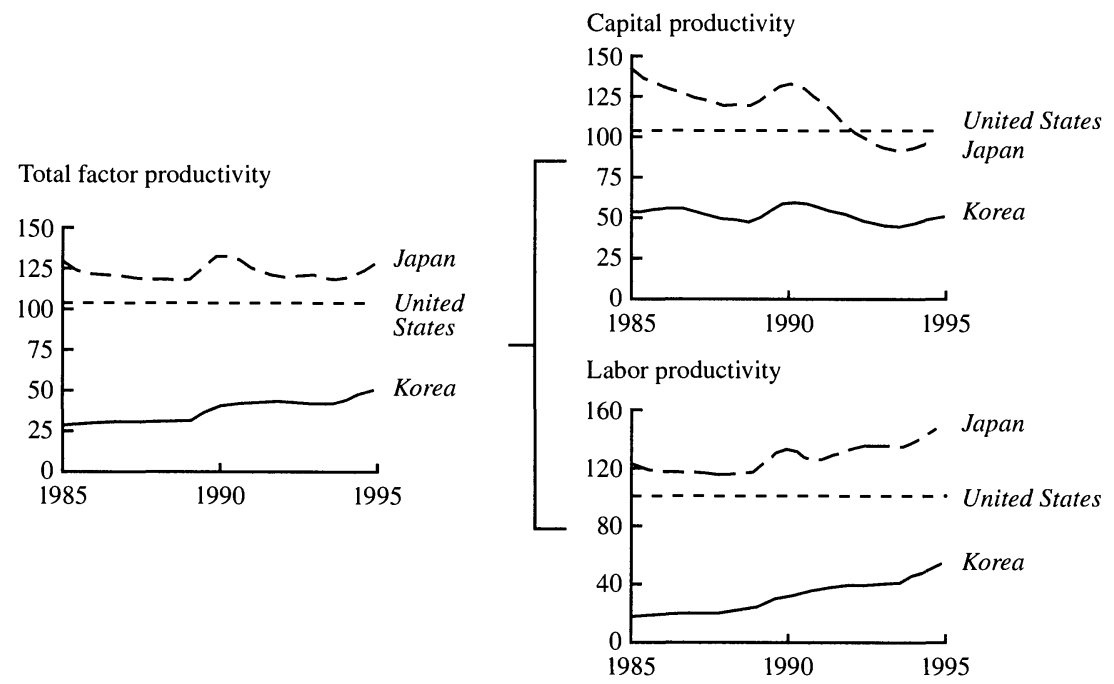

Index: United States $=100$

Source: McKinsey Global Institute (1998a, “Automotive Industry,” p. 6)

In Japan both the assemblers and the parts producers have invested very heavily, so that part of the labor productivity advantage of this industry over both the United States and Korea comes from a higher level of automation. ${ }^{17}$ For the most part, however, high productivity is achieved in Japan through a system known as "'lean production," which has been partially transferred to the United States by Japanese-owned transplants and through its adoption (often in modified form) by U.S.nameplate producers. Lean production has not fully transferred to Korea, and this is the main source of the productivity gap. Lean production differs from traditional mass production in three main areas: design for manufacturing, the conduct of supplier relationships, and the organization of production.

17. Very low interest rates and high labor costs in Japan have led to more automation than in the U.S. industry. In 1991 the U.S. and Japanese industries had similar capital intensity, but by 1995 Japanese capital intensity was 45 percent higher than that in the United States. Given the extreme factor price ratios in Japan, this extra automation is not necessarily surprising, but the fact that Korean capital intensity is equal to that of the United States despite lower wages and higher interest rates is surprising. 
-Design for manufacturing. Japanese designers increase productivity by designing cars that share common parts, often by producing multiple models from the same "platform" (chassis and power train), and that are easy to assemble. Korean cars have much less parts commonality and are rated as being among the most difficult to assemble. The average Korean OEM (original equipment manufacture) has more platforms than Honda despite producing one-third as many models and vehicles. ${ }^{18}$

The Japanese have been able to design manufacturable cars with shorter lead times in part due to strong project management that resolves conflicts between different functions early in the process. U.S. producers have shifted to this approach, but the Korean producers have maintained a traditional, functional development process. When the Korean OEMs have attempted to match Japanese lead times, they have produced a lower-quality product.

-Supplier relationships. Japanese OEMs also achieve productivity gains by collaborating with suppliers in the design of products and by helping suppliers lower their costs. The Japanese use a tiered supplier system. The limited number of top-tier suppliers receive engineering and $R \& D$ help in exchange for participating in product development and maintaining high standards of quality. Korean producers have been less successful in collaborating with their suppliers. Fewer parts are collaboratively designed, and parts design lead times are longer.

-Organization of functions and tasks. Lean production has been successful in generating continuous improvements along two dimensions: reductions in wasted time and labor during production and improvements in quality. Cycle times, the time required for a worker or team to complete activities on a car before it moves down the assembly line, are 50 percent longer in Korean plants for comparable tasks. Indirect labor per car produced is twice as high as in Japan, and a precrisis study by a Korean OEM suggested that the work force could be reduced 15 percent without any substantial reorganization. ${ }^{19}$ Strong

18. In 1996 Honda had six platforms, produced three models per platform, and averaged 300,000 cars per platform. Hyundai had seven platforms, produced just 1.4 models per platform, and averaged 157,000 cars per platform. Kia produced only 58,000 cars per platform.

19. The use of more labor in a lower-wage country like Korea may have been justified if the labor were substituting for capital, but in fact Korean companies are using 
unions in the automotive industry have made layoffs of excess workers impossible; unions have even prevented a reduction in hours worked per employee from the current 2,700 a year.

Product quality is a major issue in Korean plants; defects per car are 2.5 times the Japanese average. Hyundai owners report twice as many problems as Toyota owners to J. D. Power and Associates while Kia owners report almost five times as many. Due mainly to these quality problems, Korean cars sell for 20 percent less than comparable Japanese cars in the United States, the major market in which the two industries compete. Because producing low-quality cars requires basically the same materials, labor, and capital as producing high-quality cars, the effect of quality problems on productivity and returns is severe. Despite this, Korean automakers have focused more on increasing volume and sales and less on quality (and thus productivity and returns). Unlike their counterparts in Japan and the United States, Korean plant managers are evaluated almost exclusively on volume produced.

The automotive industry is probably one of the most difficult manufacturing industries to learn. The U.S. industry had considerably more experience than Korea in 1980, and the U.S. industry has not caught up with the best Japanese producers either in labor or total factor productivity. Toyota had a twenty-year head start on Hyundai, and therefore one might argue that it is unsurprising that Hyundai is still behind. There is reason to believe, however, that the Korean industry could have caught up more than it actually did. Auto industry productivity growth in Korea in the past twenty years has been significantly lower than in the comparable period for Japan's industry. Hyundai makes fewer cars per worker today than Toyota or Nissan did in the early 1970s (27.9 in 1996, compared with 44.7 for Toyota and 35.5 for Nissan in 1974). In addition, the Korean OEMs did not have to develop lean production on their own; they could have continued and deepened the joint ventures with world-class producers that existed in the 1960s and 1970 s, rather than attempting to be self-reliant. Self-reliance was a priority for nationalistic reasons, but it is surprising that it was maintained in the face of returns that have been well below the cost of debt since 1988. It is also surprising that the Korean industry would invest

more workers with basically the same capital input per worker as in the United States. Japan's higher total factor productivity also indicates greater efficiency. 
so aggressively given its significant productivity gap. A safer strategy may have been to attempt to match at least the United States in total factor productivity before matching it in capital intensity.

\section{Semiconductors}

The semiconductor industry is another industry recently added in Korea. From a negligible base in the early 1980s the Korean industry has grown to become the third largest in the world. It constitutes a much larger share of the Korean economy than it does in the United States or Japan-about 15 percent of exports, 15 percent of manufacturing GDP, and an even larger share of manufacturing capital stock. It also accounted for more than half the 1995 domestic value added of Samsung, Hyundai, and LG, the three largest chaebol and the major participants in the Korean semiconductor industry. The Korean economy is very exposed to changes in semiconductor prices. High DRAM (dynamic random access memory chips) prices helped fuel the economic boom in 1995, and falling prices in 1996 and 1997 (as well as large semiconductor-related capital investments) contributed to the widening current account deficit.

The Korean industry has focused on producing DRAMs, which account for 76 percent of its sales. Producing these is very capital intensive and requires manufacturing and process control capabilities, but not the design capability required to produce microprocessors and other specialized chips. This industry has not been an attractive one for investment anywhere. Aside from Intel, the semiconductor industry has not earned its cost of capital consistently. This is particularly true of DRAM production, where high fixed costs, lumpy investment requirements, and undifferentiated products have combined to produce highly volatile returns that have been lower on average than those in the rest of the industry. This is even true of Micron, which despite a 50 percent productivity advantage in DRAMs over Korean, Japanese, and other U.S. producers, has underperformed the Standard \& Poor's 500.

Korean total factor productivity is roughly 50 percent of that in the United States (figure 7), despite the fact that the overall capital intensity of the Korean industry rose from 50 percent to 100 percent of the U.S. level from 1991 to 1996 . Korean productivity is lower for three main reasons. The most important is product mix: DRAMs have less value 
Figure 7. Semiconductor Productivity, United States, Japan, and Korea, 1991-96

Total factor productivity
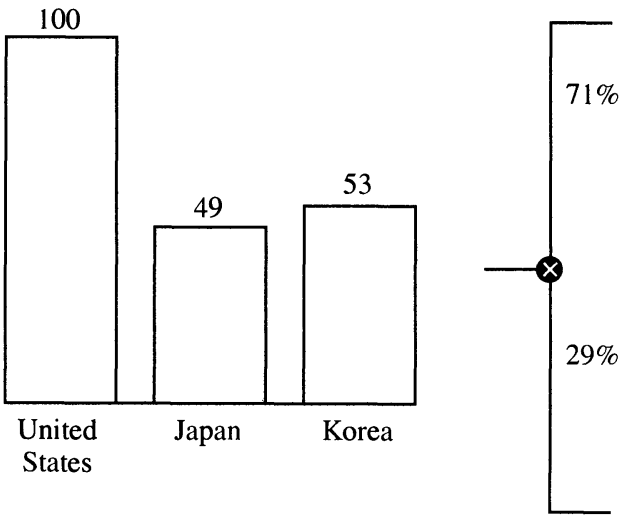

Capital productivity

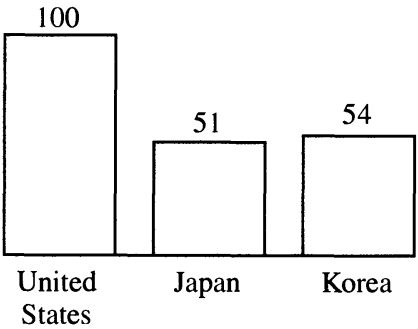

Labor productivity

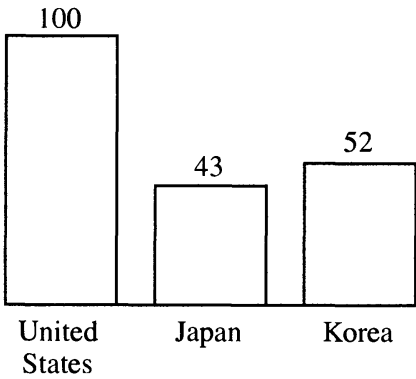

Index: United States $=100$

Source: McKinsey Global Institute (1998a, “Automotive Industry,” p. 7).

added per unit input than the average product produced in the United States. This is mainly due to the disadvantageous market structure of the DRAM industry and the advantageous market structure of the microprocessor industry. Intel alone accounts for one-fifth of the U.S.Korea productivity gap. ${ }^{20}$ The second reason is that Korea has a higher share of chip assembly activities, which are lower-productivity activities than chip fabrication and thus bring down the Korean average. The final reason is the difference in operational performance of the U.S. and Korean producers. This gap is due to the non-DRAM Korean pro-

20. Our analysis includes 1996. Since 1996, Intel's market position has weakened somewhat, although microprocessors have remained a more profitable and higherproductivity (high value added per unit of total factor input) product than DRAMs. 
duction; Korean DRAM producers have caught up with the average U.S. producer, although not with such best-practice producers as Micron. The Korean average hides substantial differences in DRAM productivity among the three companies; Samsung is within 15 percent of Micron, while Hyundai and LG have achieved 60 percent and 45 percent of Micron's productivity, respectively.

The entry of Korean companies into semiconductor production has been cited as an example of successful entry into a technologically advanced industry. ${ }^{21}$ And there is no question that the achievement of establishing this industry and becoming one of the world's leading producers has been considerable. Transferring the technology and developing the production skills were challenging. But despite this success, overall Korean productivity and returns on investment have been disappointing, raising the question of whether the heavy investments in this industry have been wise economic and business decisions.

One defense of Korea's investment decisions is that it may be too early to judge the returns. The Korean producers may ultimately win the technology race and reap high profits. Alternatively, one could argue that the decision to enter this industry was sound; but like all investments these were subject to uncertainty, and events have not turned out as expected. It was not as easy to see in the mid-1980s as it is in hindsight that the profitability of the DRAM industry would be so low, that the spillover benefits to the rest of the economy would be so limited, or that the escalation of investment would require Korea to become so dependent on its big bet in semiconductors.

In our judgment, however, this defense of the decision to invest heavily in this industry does not hold up. First, even precrisis market valuations of semiconductor companies suggested that investors did not believe that this would be a profitable industry any time soon. Second, it is hard to argue that this was an early mistake, made before the status of the industry was revealed. Almost half the total Korean investment in semiconductors has been made since 1995. Despite the deteriorating performance of the industry, Korean investment plans were accelerating until the financial crisis forced their postponement. This suggests the explanation lies with the corporate governance and investment decisionmaking of Korean firms, a theme to which we return later.

21. See, for example, Kim (1997). 


\section{Steel Minimills}

Steel minimills account for about one-third of the Korean steel industry. Unlike integrated mills, which produce a wide range of products from iron ore and coking coal, minimills produce a narrow range of commodity long products (for example, wire rod, reinforcement bar) from scrap sheet that is melted in an electric arc furnace. The minimum efficient scale is much lower for minimills, and capital requirements per ton are also lower. In Korea the government-owned Pohang Iron and Steel Company (POSCO) is the only integrated producer; the minimills are almost all privately owned.

Unlike POSCO, which has productivity slightly above the Japanese average, Korean minimills have only 65 percent of Japanese labor productivity despite roughly equivalent capital intensity. ${ }^{22}$ Best-practice minimill producers such as Tokyo Steel and U.S.-based Nucor have achieved high productivity by taking advantage of the simple product mix and small scale of minimills to streamline management and processes. Nucor manages more than 4,000 employees with only four management layers, compared with up to ten in a traditional integrated producer. Fewer management layers combines with the small size of a typical minimill (200 to 500 employees compared with 5,000 to 10,000 at large integrated plants) to increase accountability of both production workers and management. Both Nucor and Japanese minimills have adopted practices such as cross-training workers to handle multiple tasks, limiting the number of products produced in a given mill to reduce change over time, and using continuous improvement programs to increase productivity.

Korean minimills have lower productivity mainly because they have not adopted Japanese and U.S. best practices. For example, Korean mills make less use of multitasking. In Japan the three main production tasks of sampling, handling, and inserting scrap steel into the electric arc furnace are handled by one person, whereas Korean minimills use three. Korean companies also attempt to produce a mix of products in each minimill, while Japanese minimills specialize in particular prod-

22. Because of data limitations, we are not able to estimate separate capital and total factor productivity measures for minimills and integrated producers. Most of the capital in a minimill is in the furnace, caster, and rolling mills, and there is little scope for varying capital intensity to match factor prices. 
ucts. ${ }^{23}$ In some cases, antilayoff laws have prevented Korean minimills from making feasible productivity improvements. In addition, there are some small differences in the automation of materials handling. These reduce Korean labor productivity, but not necessarily total factor productivity, compared with plants in Japan.

Despite their low productivity, Korean minimills have earned returns that are above their cost of debt. ${ }^{24}$ Unlike POSCO, which under government direction sells its (mainly flat) products domestically at an average of 12 percent less than world prices, minimills are able to take advantage of tariffs and transport costs to charge prices that are about 10 percent above world prices.

This pricing difference helps the minimills earn acceptable returns despite low productivity. POSCO is implicitly forbidden from entering the product segments of the private minimills, which prevents it from putting them under more competitive pressure.

\section{Food Processing}

To provide a complete picture of manufacturing, it was important to include a large domestic consumer goods industry, and we selected food processing. Given the diversity of products involved, we focused on two minicases within the sector, choosing both a high-capital-intensity segment-confectionery-and a low-intensity segment-wet corn milling. The outputs of these industries were reasonably comparable among the comparison countries.

CONFECTIONERY. The confectionery sector has 42 percent of U.S. total factor productivity despite a capital intensity equal to 112 percent of that in the United States. It is the largest of the processed food subindustries in Korea, accounting for 15 percent of processed food value added and is representative of a large number of subindustries such as bakery goods, seasoning, and fats and oils that have high capital intensity but low productivity-confectionery is roughly equally

23. Small industry size does not account for the lack of specialization in Korean minimills. They produce 13 million tons a year (compared with 26 million in Japan and 25 million in the United States), which makes the industry large enough to have plants efficiently specialize.

24. Minimills earned a return on invested capital of 16 percent from 1985 to 1995 , compared with a cost of debt of 14 percent. POSCO earned 8 percent compared with a (subsidized) cost of debt of 7 percent. 
Figure 8. Estimated Labor and Capital Productivity Differences in Confectionery Industry, United States and Korea, 1995

Labor productivity

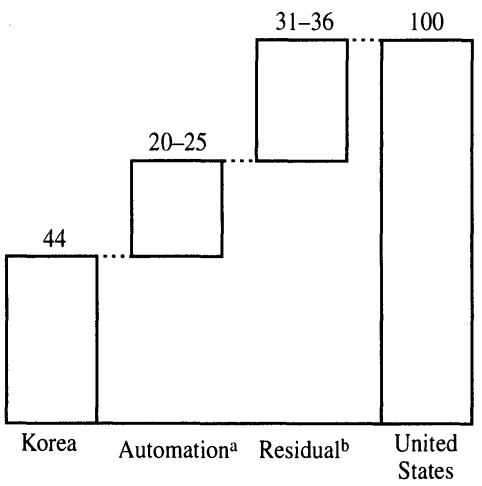

Capital productivity

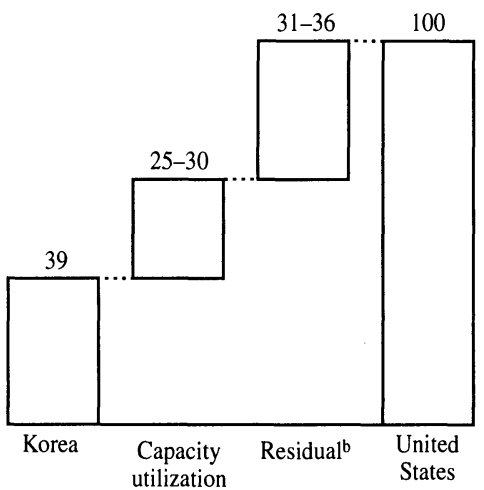

Index: United States $=100$

Source: McKinsey Global Institute (1998a, "Processed Food Industry," p. 8).

a. Packaging lines.

b. Includes marketing and organization of functions and tasks.

divided into chocolate and candy, cookies (biscuits), and ice cream. In confectionery, capital intensity has risen 11 percent a year from 1987 to 1995 , the same rate as for the industry as a whole.

Total factor productivity is low despite high capital intensity because of three main problems: misallocation of capital (resulting in overinvestment in some areas but inadequate automation in others), low capacity utilization, and poor organization and marketing (figure 8). Packaging is much less automated than in the United States, which increases labor requirements by 50 percent in an activity that accounts for about half of total labor. Despite this automation gap, the Korean industry has more capital per worker hour overall because of very low capacity utilization. A typical Korean production line operates 40 percent fewer hours a week than a line in the United States; capacity utilization in Korea was an estimated 37.5 percent in 1997, compared with 62.5 percent in the United States. Most of this difference is due to insufficient demand for the products that the lines are designed to produce. ${ }^{25}$ Most of these lines were built

25. This conclusion was reached based on interviews made in early 1997 , before the current crisis. Managers told us that this problem existed to roughly the same extent in 1995, the most recent business cycle peak. 
to produce poorly researched products that did not sell as expected. U.S. producers avoid these overcapacity problems by conducting more careful market research and producing products on more flexible, less dedicated production lines until the products are proven successful.

In addition to creating overcapacity, poor execution of the marketing function has directly created productivity problems. Korean firms have produced large numbers of poorly differentiated products, in many cases producing "me-too"' copies of competitors' products rather than developing original high-value products. Sales per product are onetenth as large as in the United States, which creates scale-related productivity penalties. Sales and market share goals rather than profitability or shareholder returns have driven Korean product development. Representative comments from interviews include: "Our key performance measurement has been sales growth rather than profit growth," "we often produce 'me-too products' to protect our market share even though these products may negatively impact long-term profit performance," and "as we have been focusing on sales growth, we have not been very good at eliminating dead products.',

WET CORN MILLING. We chose wet corn milling because it is the largest subsegment of milling, which is in turn the largest of the lowcapital-intensity food processing industries. The industry produces products such as starch, high-fructose corn syrup, and glucose. The capital intensity of wet corn milling is 24 percent of the U.S. level and total factor productivity is 44 percent. Unlike most of the rest of food processing and manufacturing, wet corn milling has not invested to developed-country levels.

The industry is in a situation similar to that of other Korean processed food industries before rapid investment in them began about ten years ago. Most corn milling plants in Korea are more than twenty years old, have outdated equipment, and are unable to produce products with higher value added. Plant scale is on average one-fifth of that in the United States. Korean plants are overstaffed compared with U.S. plants, and product yields are lower.

Globally, wet corn milling is handled by multinationals that transfer best practices into plants in Latin America, Africa, and elsewhere in Asia. The Korean industry consists of only five companies, entry by foreign companies was prohibited until 1996, and import quotas were in place on major products. As with other low-capital-intensity pro- 
cessed food industries (such as noodles and corn oil), large Korean companies have been prohibited from entering the sector. Wet corn milling is the only manufacturing industry we studied from which the chaebol were absent, which may help explain its less than average capital intensity.

\section{Integrated Steel Mills}

Integrated steel mills are the one highly productive industry we studied. Interestingly, this sector consisted entirely of a government-owned company, POSCO. The company owes its high productivity to modern, large, and efficiently laid out facilities at Kwangyang and Pohang. Unlike older steel plants, such as those in the United States, which grew gradually and contain older casting technology and furnaces and rolling mills that are smaller than efficient scale, the POSCO facilities are well planned, use the latest technology, and are laid out in a manner that minimizes materials handling effort. Unlike many of the other Korean manufacturers we studied, POSCO has tried to match its labor productivity against that of the best Japanese producers and has increased it steadily.

How did a government-owned company accomplish what few private Korean companies were able to? Much of the credit is probably due to Taejoon Park, who was chairman of POSCO from 1968 to 1994. Park, a former general, accepted his position on the condition that there be no government interference in the company's procurement and staffing decisions. He then instituted modern Japanese and Western management practices that were absent in other Korean companies. POSCO continuously matched itself against world best practice, conducted an assessment based on net present value of new investment projects, and sourced its capital equipment globally. The company has a strong anticorruption ethic and has demanded very high performance from its suppliers. The government helped keep the pressure on POSCO by requiring that it sell steel domestically at less than world prices. Whereas many steel industries in emerging countries (including the Korean minimill industry) price at import parity (the world price plus tariffs and transport costs), POSCO has priced at export parity, the price below which domestic customers could export its steel at a profit. ${ }^{26}$

26. Amsden (1989). 
That POSCO has been well run makes it something of an exception among state-owned enterprises we have studied in many countries. Its leadership has likely been a special case that tests the usual rules. Moreover, it is an exception among Korean industries in that it has consistently earned its cost of capital. Although its capital costs are subsidized, this subsidy is more than repaid through the low prices the company charges domestic customers. Allowing POSCO to charge world prices on its domestic sales would increase its return on invested capital (ROIC) by roughly 6 percent, and allowing it to charge import parity prices like the private minimills would increase it by another 5 percent. If import parity is viewed as the opportunity cost at which Korea could have acquired steel had POSCO not existed, the company's true return on invested capital over the past ten years is roughly 19 percent, well above even a nonsubsidized cost of capital.

The success of POSCO, of course, is not final. Chairman Park has retired, and it is possible that the company will revert to performance more typical of state-owned enterprises. This is part of the rationale for the government's plan to privatize POSCO and potentially even divide it in order to achieve domestic competition. It is also essential that the company avoid overbuilding capacity the way Japan did in the early 1970s. Experience has shown that domestic demand for steel grows rapidly until GDP per capita reaches about $\$ 10,000$ and then slowly declines. Japan continued to build capacity as its GDP per capita grew past this level; the result was massive excess capacity, which has destroyed its returns and forced painful restructuring (figure 9). Exporting its excess steel production became less viable as labor costs increased. Even without considering the effects of the financial crisis, Korea is now nearing the point where domestic steel demand will begin to slow, and it needs to manage its capacity carefully.

\section{Services and Construction Cases}

Services and construction together employ twice as many workers as manufacturing. Although industry-level capital data are more difficult to obtain in the service sector, aggregate data suggest that services as a whole have about 20 percent of U.S. capital intensity, compared with 57 percent for manufacturing, and that average capital productivity is 
Figure 9. Crude Steel Production and Capacity per Capita, Korea and Japan

Thousand of tons

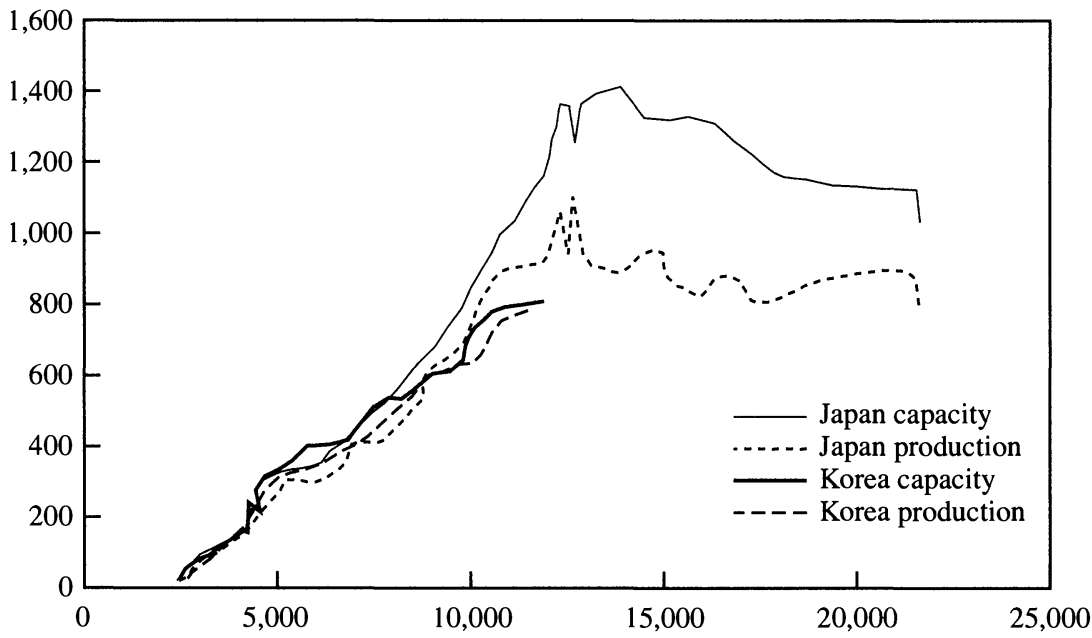

GDP per capita (1995 U.S. dollars at purchasing power parity)

Source: McKinsey Global Institute (1998a, "'Steel Industry," p. 14).

much higher in services and construction. Given this difference in average (and presumably marginal) productivity, why has so little investment been made in the nonmanufacturing sector?

To answer this question, we examined four industries that cover about one-third of total market employment in the nonmanufacturing sector. Given the diversity of the sector, it is hard for any sample to be fully representative, but analysis of these four industries gives both a range of reasons for the successes and failures of this part of the economy and uncovers common themes that help explain the overall result.

\section{General Merchandise Retailing}

The retail industry is a large employer in any economy; in Korea it accounts for 12 percent of service and construction employment, so it is an important for the country's overall economic performance. In addition, retail employment often expands as economies grow and can create new jobs at a time when employment is declining in other indus- 
tries. ${ }^{27}$ Our productivity analysis focused on general merchandise (nonfood) retailing, the larger and more complex segment of the industry. Hereafter, retailing will refer only to general merchandise retailing. ${ }^{28}$

In all developed and middle-income countries, retailing is evolving from traditional mom-and-pop stores to more productive formats such as department stores, discounters, and specialty stores. These formats achieve high productivity (high value added per unit of input) either by providing goods to consumers efficiently (high sales per unit of input) or providing a shopping service for which customers are willing to pay extra (high ratio of value added to sales) ${ }^{29}$ Discounters such as WalMart or Costco tend to focus on high efficiency, while department stores and specialty chains provide a high level of service by supplying attractive surroundings and knowledgeable sales personnel (Nordstrom) or a range of goods targeted on a limited group of consumers (J. Crew). All of these advanced formats use information technology and the advantages of a large-scale firm (not necessarily large-scale stores) to achieve more productive logistics and purchasing and to better target customers' needs.

In Korea the evolution toward higher-productivity stores has been slower than would be expected given the country's income level. Korean stores are much smaller than those in the United States or Japan,

27. Retail employment has not expanded in France and Germany because of high labor costs and product market barriers such as strict (and often anticompetitive) application of zoning laws. This is a major contributor to the unemployment problem in these countries. See McKinsey Global Institute (1997).

28. The sectors in the three countries were adjusted in order to achieve comparability. Specifically, eating and drinking, gasoline service stations, and automotive dealers in the United States; gasoline service stations in Japan; and personal and household goods repair in Korea were all excluded from our study.

29. With cross-country comparisons, it is difficult to determine if low ratios of value added to sales reflect low real service levels or a low price of retailing service (because of low minimum wages, for example). Ideally, one would want to convert value added to a common currency using a double-deflated PPP for retailing service, but we have found this impossible given available data. For this study we used the PPP for private consumption expenditure as a proxy. In our studies of retail productivity in the United States, France, Germany, and the Netherlands, we have experimented with other methodologies, such as assuming that workers in the same format have identical productivity across countries or that workers in a given multinational store (Ikea, for instance) have the same productivity in all countries. In general we found that the results varied by about 10 to 15 percent depending on the methodology; an error of this magnitude would not affect the conclusions drawn from the U.S.-Korea comparison. See Baily and Zitzewitz (1998) for details. 
Figure 10. Estimated Retail Store Labor Productivity, by Type of Store, United States and Korea, 1992

Productivity by format

U.S. 1992 average labor productivity $=100$

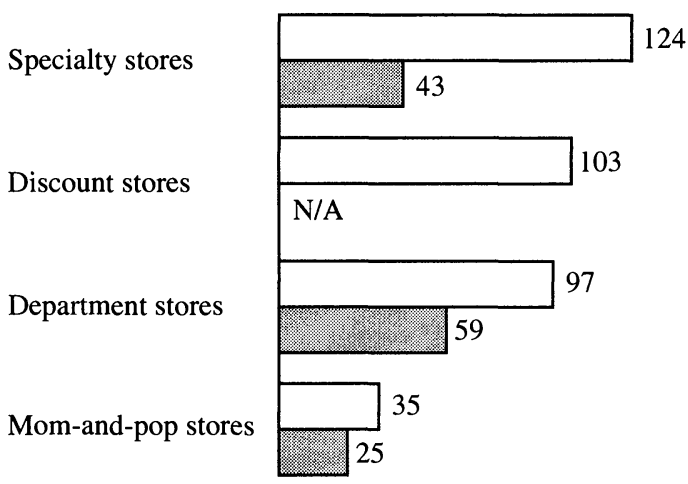

$\square$ United States $\quad$ Korea

Index: U.S. 1992 average labor productivity $=100$

Source: McKinsey Global Institute (1998a, “Retail Industry,” p. 8).

with 2.2 employers per store compared with 4.7 in Japan and 8.0 in the United States, and 99 percent of all retail stores operate as single units, not as part of a chain. More than 70 percent of the workers in Korean retail stores are proprietors or unpaid family members. Korean retail is composed mainly of traditional, low-productivity, mom-and-pop stores, whereas the U.S. sector is 80 percent advanced formats (figure 10). As a result, Korean labor productivity is only 32 percent of the U.S. level (figure 11) because of lower efficiency (ratio of sales to input) and lower ratios of value added to sales. ${ }^{30}$

In addition to the different format mix, advanced Korean formats are less productive than their U.S. counterparts. Korean department stores achieve only 59 percent of U.S. department store productivity, while

30. Because value added data were not available in all countries, we use gross margin as a proxy for value added. Gross margin causes problems in that it includes purchased services, which could bias the results in favor of stores with disproportionate purchases of services such as advertising. At least for a subset of Korean stores for which we had both figures, however, this bias was very small. Another data problem is that the retailing censuses on which our results are based are not conducted in the same years in all countries; our comparison uses different base years-1993 for Korea, 1992 for the United States, and 1994 for Japan. 
Figure 11. Retail Sector Labor Productivity, United States, Japan, and Korea

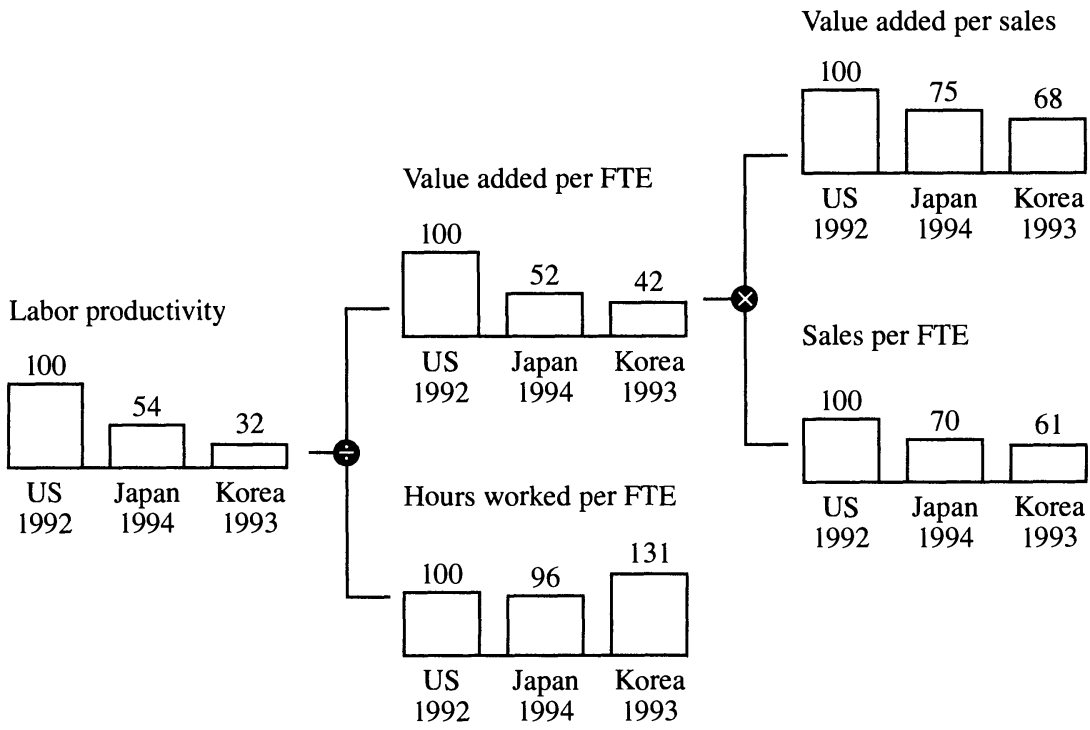

Index: United States $=100$

Source: McKinsey Global Institute (1998a, "Retail Industry," p. 7). Value added calculated using consumption purchasing power parity. FTE is full-time equivalent employees.

specialty stores reach just 43 percent. ${ }^{31}$ The McKinsey Global Institute's review of work practices in Korea found that department and specialty stores did not deploy their work forces efficiently, providing low levels of service despite large numbers of staff on the floor. There was ineffective use of point-of-sale information, and merchandising was not best practice, as seen, for example, in the lack of category management skills.

The main reason advanced formats have emerged only slowly and foreign retailers have not transferred best practices (as they have in Brazil and other middle-income countries) is Korea's land use policies. Land in Korea is scarce, and intricate zoning and land development laws govern both its availability and use. Until 1993 the National Land

31. A productivity comparison for discount stores is not included because there were no discount stores in Korea during the year of our study. Some of the gap in specialty store productivity may be explained by format mix within categories: many Korean specialty stores were mom-and-pops, while U.S. specialty stores were more advanced category killers such as Home Depot or Circuit City, which are highly productive. 
Usage Management Act prohibited stores larger than 1,000 square meters from operating in any area outside the urban zone. The Urban Planning Act and the Construction Act again restricted the commercial area that could be used for retail formats larger than 1,000 square meters. Known as urban commercial areas, these zones are conveniently located to generate very high sales traffic. Unfortunately, the available locations are often already occupied by retailers or office buildings or too small to accommodate department stores, discounters, or the shopping malls that make advanced specialty stores viable. Retailers could have redeveloped these attractive commercial locations in urban areas by buying smaller buildings, tearing them down, and building a large store. However, many retailers pointed out that redeveloping existing retail stores is a cumbersome option because of the long, complex negotiations required to get agreement from multiple owners.

Land use policies also contribute to the high cost of urban land by concentrating the population in city centers and preventing the development of edge cities. This problem is made worse by the policy-related pressure on the population to concentrate in Seoul. Only 0.2 percent of the land area in Korea is designated for commercial use, suggesting that policy, not intrinsic factor endowments, is the larger problem.

Special land use policies have restricted the entry of advanced foreign retailers. Most advanced formats need at least 5,000 square meters to operate efficiently. Before 1984, only retail outlets less than 200 square meters and selling only one type of product were allowed to enter Korea. In 1984 shop sizes of 700 square meters and selling multiple product types were allowed. In 1991 the first step of a three-stage deregulation allowed foreign investment in up to ten stores less than 1,000 square meters in lot size. The second step in 1993 allowed store sizes of up to 3,000 square meters, and the number and sizes of stores was completely deregulated in 1996. Thus until 1996 foreign retailers were effectively limited to subscale discounters and the few small specialty stores that could survive outside of shopping malls. Even now, foreign retailers face the same land use laws as domestic firms.

A host of additional regulations, such as restrictions on chaebol involvement in retail activity and an arduous, bureaucratic store-opening evaluation process contributed to Korea's low productivity. These regulations were established with the objectives of protecting momand-pop stores, discouraging consumption, and promoting more in- 
vestment in manufacturing industries. Figures on capital intensity and productivity for the entire trade sector suggest that the policies were successful in diverting investment: capital intensity in trade is only 21 percent of that in the United States, while capital productivity is roughly 150 percent, double that of Korean manufacturing. By diverting capital from trade to manufacturing, Korea diverted capital to low-productivity investments and closed off potentially high-return investments in retail.

There are parallels between retailing in Korea and in Japan. In previous work on this sector, we found that land use and other restrictions had prevented the evolution of retailing in Japan, just as it has done in Korea. ${ }^{32}$ More recently, Japan has opened up the sector to some extent to foreign retail chains and has allowed the development of Japan-based discounters, thereby increasing productivity. ${ }^{33}$

\section{Construction}

The construction industry in Korea accounted for 16 percent of GDP and 8.5 percent of employment in 1995 . In the past ten years, construction has experienced compounded annual growth of 17 percent in value added and 8 percent in employment. Most of this growth has occurred since 1989 when the government announced that it would construct 2 million houses to resolve the housing shortage and relaxed industry entry restrictions. ${ }^{34}$

The construction industry can be divided into three segments: residential, nonresidential, and heavy construction, each accounting for roughly one-third of sales and employment. Residential construction includes both private and public housing construction, nonresidential includes commercial and industrial structures, and heavy construction includes infrastructure such as bridges and roads. Although we report productivity estimates for all three types, our analysis focuses on residential construction.

Based on value added at purchasing power parity (PPP), overall

32. McKinsey Global Institute (1992).

33. Because of its very restrictive land use policy, Japan may find that discounters and category killers drive out the mom-and-pop stores, but the lost employment is not replaced by specialty retailing. This type of retailing requires the development of shopping malls, or some equivalent mechanism, to generate customer traffic.

34. The compounded annual growth rate of value added from 1989 to 1995 was 27 percent. 
Figure 12. Labor Productivity in the Construction Industry: Value Added per Hour Worked, United States and Korea, 1995

Construction productivity

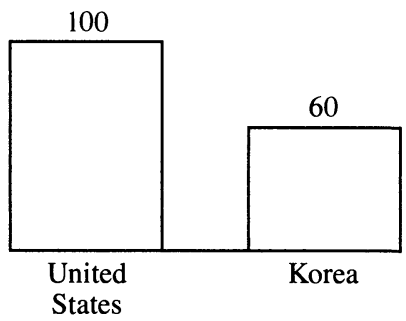

Residential productivity

100

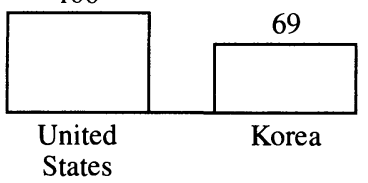

Non-residential productivity

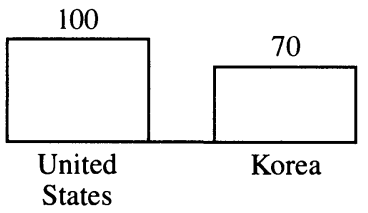

Heavy construction productivity

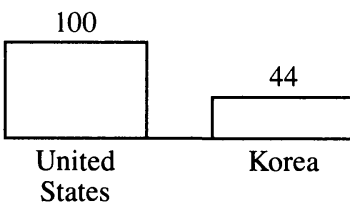

Index: United States $=100$

Source: McKinsey Global Institute (1998a, “Construction Industry," p. 5).

Korean labor productivity is 60 percent of that in the U.S. industry, with residential construction productivity at 69 percent of U.S. value added per hour worked (figure 12). ${ }^{35}$ For residential construction we also computed a physical measure of output (square meters) and found that Korean physical productivity-square meters per hour-is 93 percent of the U.S. level, but the value added for each square meter built is only 75 percent of the U.S. level. The value added per square meter is constrained by regulation. Government regulations have set a price ceiling for units in apartment buildings, which encourages developers to design small units with poor-quality fixtures and few appliances. It

35. The best available residential construction PPP was from the 1985 UN International Comparisons Project, which was updated using national construction GDP deflators. 
is common practice in Korea for a purchaser to immediately renovate a newly constructed unit to upgrade the contents. The price cap also keeps net margins low ( 0.7 percent as opposed to 5.0 percent in the United States), which discourages larger-scale developers from consolidating the industry. We estimated that the inefficiencies associated with the price cap account for 10 percent of the productivity gap.

In addition, land use policy in Korea shifts the mix of units toward multifamily housing. Although these units allow the construction of more square meters per hour worked, single-family housing generates higher value added per square meter. Copying the U.S. mix of singlefamily homes may be impractical because of Korea's higher population density. But other similarly populated countries, such as the Netherlands, have achieved high productivity and higher shares of singlefamily and medium-density housing while preserving green space. (Residential construction productivity in the Netherlands is the same as in the United States).

Korean productivity is also lower because of the absence of operational best practices. Based on interviews with industry participants, the problems most commonly cited were:

-Less standardization. Housing construction in the United States and the Netherlands is usually handled by developers who manage a number of large projects. This allows standardization in designs and in the sizes and quality of construction materials and allows firms and workers to benefit more from learning by doing. Residential construction is much more fragmented in Korea.

-Poor project management, especially in the design phase. Unlike in the United States and the Netherlands, where a lead contractor with proper incentives manages projects from design to completion, in Korea the process is again more fragmented. This leads to communication problems and more frequent revision of designs.

-Less productive construction methods. Many construction methods used in Korea require more steps and labor hours. For example, Korean housing often has in-floor heating, which takes 30 percent longer to install than standard heating. Korean housing also usually has concrete walls instead of drywall, and concrete walls take almost twice as long to construct.

Like retail activity, residential construction is a sector in which productivity, output, and investment have been limited by both land use 
regulations and the absence of large companies that have adopted modern business practices. However, residential construction, at 69 percent of U.S. productivity, does appear to be more advanced than retail.

\section{Telecommunications}

Although the Korean telecommunications industry was deregulated in 1996, like many recently deregulated industries, it is still dominated by the state-owned former monopoly. Korea Telecom accounts for 80 percent of industry revenue, but even though it still has a local monopoly, it has faced competition from DACOM in international calling since 1991 and domestic long distance since 1996. Mobile services have experienced more deregulation: the market already has two national cellular companies and three mobile telephone providers. The government issued thirteen additional licenses in 1996. The Korean government still owns 71 percent of Korea Telecom, but it plans to reduce this share in the coming years.

The Korean telecommunications industry has achieved a network development that ranks among the world's fastest. The number of access lines per hundred inhabitants, grew from 3.0 in 1975 to 41.5 in 1995, an average annual increase of 14 percent. Most of this growth was in fixed lines, but recent growth in the number of mobile subscribers has been extremely rapid. Korea has also taken major steps to improve the quality of its network: the share of digitally switched lines has increased to 63 percent.

Korea combined this rapid network growth with fairly high labor productivity. Since its rapid network growth began in the late 1970s, access lines per employee have been comparable to those in the United States (figure 13). The experience of other developing countries reveals that this achievement is not automatic (Brazil), nor is it final (Mexico, Hong Kong). The Korean telecommunications industry has captured much of the productivity benefit of new technology, rather than applying the new technology while maintaining staffing levels as other telecommunications industries have done. This has been made easier by rapid network growth; the country has been able to increase productivity by limiting its employment growth rather than having to lay off workers who were hired to staff a lower-technology network.

Although the number of access lines per employee is higher than in 
Figure 13. Telecommunication Access Lines per Telecommunications Employee, Five Countries, 1975-95

Lines

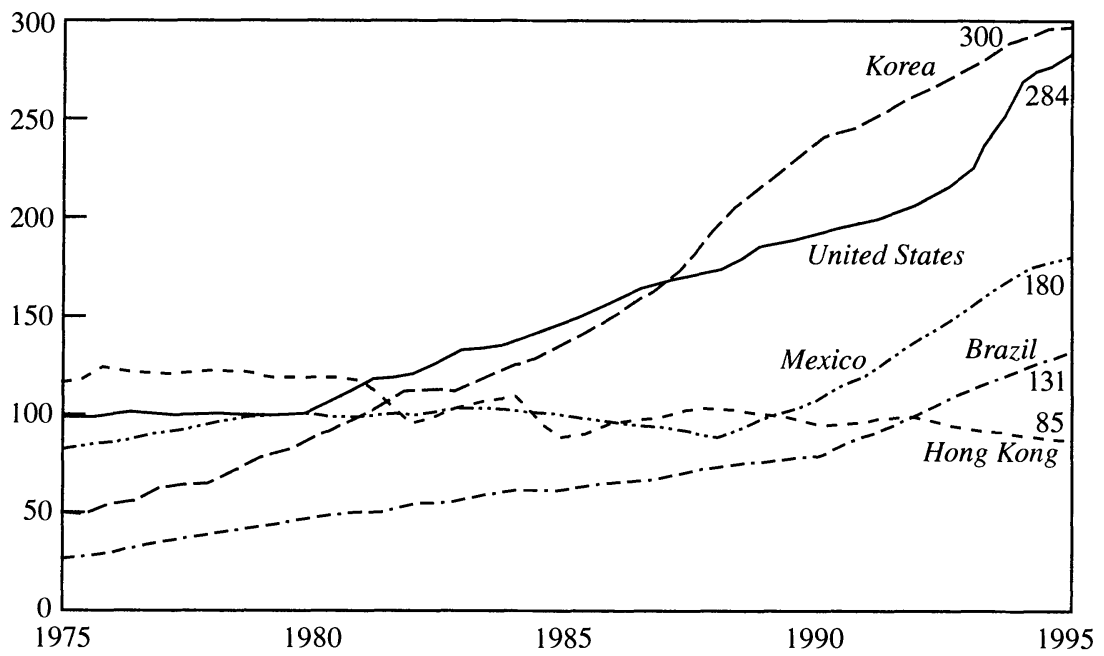

Source: McKinsey Global Institute (1998a, "Telecommunication Services Industry," p. 17). Telecommunications employment as reported to the International Telecommunication Union.

the United States, labor productivity overall is only 83 percent of that in the U.S. industry, mainly due to longer hours worked in Korea (table $2)$. Interviews suggested that the long working hours $(2,700$ a year) were unnecessary and could be reduced without affecting service quality. Long hours appear to result from internal evaluation procedures that emphasize "face time", (time spent at work) rather than quality of

Table 2. Telecommunications Productivity, 1995

Index: United States $=100$

\begin{tabular}{lccc}
\hline & $\begin{array}{c}\text { Capital productivity } \\
\text { Call minutes per }\end{array}$ & \\
Country & Access lines, call & $\begin{array}{c}\text { U.S. dollar capital } \\
\text { service }\end{array}$ & $\begin{array}{c}\text { Total factor } \\
\text { productivity }\end{array}$ \\
\hline United States & 100 & 100 & 100 \\
Japan & 82 & 39 & 51 \\
Brazil & 41 & 77 & 62 \\
Korea & 83 & 58 & 66 \\
\hline
\end{tabular}

Source: McKinsey Global Institute (1998a, “Telecommunication Services Industry," p. 7). 
Table 3. Average Use Per Access Line, 1995

\begin{tabular}{|c|c|c|c|c|c|c|}
\hline Country & Local calls $^{\mathbf{a}}$ & $\begin{array}{c}\text { Long } \\
\text { distance }^{\mathrm{a}}\end{array}$ & $\begin{array}{l}\text { International } \\
\text { and mobile }\end{array}$ & $\begin{array}{c}\text { Annual } \\
\text { calls per } \\
\text { line }\end{array}$ & $\begin{array}{l}\text { Call minutes } \\
\text { per capita }\end{array}$ & $\begin{array}{c}\text { Average } \\
\text { minutes } \\
\text { per call }\end{array}$ \\
\hline United States & 5,703 & 2,037 & 280 & 8,020 & 5,955 & 2.70 \\
\hline Japan & 1,822 & 1,428 & 206 & 3,456 & 1,983 & 2.64 \\
\hline Brazil & 6,278 & 1,288 & 102 & 7,668 & 779 & 2.80 \\
\hline Korea & 3,662 & 1,429 & 90 & 5,181 & 2,376 & 1.51 \\
\hline
\end{tabular}

Source: McKinsey Global Institute (1998a, “Telecommunication Services Industry," p. 7).

a. The definition of local and long distance calls (in terms of distance covered) differs by countries and regions.

work. The fact that most employees are salaried makes the problem less obvious to top management.

The larger issue, however, is capital productivity. Network utilization (call minutes per unit of capital stock) is only 58 percent of the U.S. level, mainly because of fewer call minutes per access line. Koreans make fewer and shorter calls and more local than long distance calls (table 3). The conclusion is similar to the one we have reached for Japan and many European countries: the United States has greater network utilization than most countries. Many factors influence demand for and use of telecommunications services, and isolating their impact is empirically difficult. We have found in past studies that U.S. demand is significantly influenced by sophisticated and aggressive marketing, low marginal pricing of calls, and the availability of services that promote call initiation and completion.

In Korea the factors that drive high U.S. demand appear to be absent. Marketing activity has been limited. In fact, during the 1980 s, when Korea was focused on expanding its network to meet demand, Korea Telecom actually encouraged low usage: "Tonghwa nun kandan hee", ("Call brief') was one of its slogans. The company prices local calls by the minute rather than providing free local calls for a fixed monthly charge. Business use of the telephone has not been promoted, and uses such as telemarketing, teleconferencing, toll free calling, and electronic transactions are much less common. Some of the lower business and residential telephone usage may be due to lower income levels, but the contrast in the marketing and pricing strategies of U.S. and Korean carriers suggest that income is not the whole story. ${ }^{36}$

36. Korean telecommunications use, and therefore productivity, may also depend on the age of the industry. The United States developed its telephone network more than 
In addition to low network utilization, Korean capital productivity is also reduced by its higher capital cost per access line. The government encouraged Korea Telecom to work closely with domestic equipment manufacturers to develop advanced switching technology. The government viewed the development of domestic switching technology as a means to reduce dependence on foreign equipment makers and to provide a source of exports. Korea achieved some success in duplicating overseas technology, but at a cost. Korean investment per line was 12 percent higher than it was in the United States. Detailed data on switch prices in Korea were not available, but industry experts estimated that Korean prices were 10 to 20 percent higher than those in the United States.

The Korean telecommunications industry is a mixture of good and not-so-good performance. In some respects it resembles the integrated steel industry. Development of a modern telecommunications network was seen as a priority for the country, and a state-owned industry was established with access to capital and a mandate for rapid growth. Korea's relatively late economic development allowed it to take advantage of best practices and new technologies. ${ }^{37}$ The country was able to engage in extensive knowledge and technology transfers with the more developed countries. In addition, interviews with Korean service providers indicate that they actively sought telecommunications experts from the more advanced economies and attempted to learn from their experience. Unlike steel, however, Korea Telecom did not export and did not have to provide service at international prices. Also unlike steel, promoting high output (network usage) was not a priority, and marketing and pricing reflect that. Interviews suggested that despite deregulation efforts, Korea still views Korea Telecom as a national asset, suggesting that although some formal barriers to competition have been

a generation before the world's other advanced economies. As a result, calling patterns in the United States may be more mature than those in other countries. America has developed a culture of phone use that does not currently exist in Korea and has oriented its economic activity around telecommunications to a greater extent. In telecommunications there are positive network externalities (for instance, the value of the network to subscribers, and the likelihood they will use it, increases with the size of the network). U.S. subscribers may demand comparatively more telephone service because of the country's larger network, and Korea's use may increase as its network expands.

37. The advantage may be offset, however, by more developed markets and usage patterns in the United States. 
removed, competitive intensity is still restrained by policies favoring the company.

\section{Retail Banking}

The Korean government has historically used the banking sector to advance its overall development goals by encouraging high personal savings rates, capturing the savings within the formal banking system, and channeling them to high-priority industries. The government nationalized the banks in the $1960 \mathrm{~s}$, and although they have since been privatized, government influence remains strong. In the 1960s time and savings deposits in the formal banking system increased from 1.8 percent to 20.7 percent of GDP, mainly due to changes in interest rates that encouraged saving and attracted savings away from informal lenders. Saving was also encouraged by the restriction of consumer finance; Koreans were encouraged to save for a home through the Korean Housing Bank because mortgages were difficult to get. Banks were prohibited from lending to certain industries, such as leisure and real estate, and were encouraged to lend to export-oriented sectors such as manufacturing and overseas heavy construction. ${ }^{38}$

Banks have a dual function in modern economies. First, they allocate saving to finance business and consumer investment, presumably in a way that makes good use of a country's scarce capital. Second, they make payments, maintain deposit and loan accounts, and provide other banking services to retail business customers. This case study examines how productive Korean banks are in providing services. To understand how well they have done in allocating savings, we look at capital productivity and allocation in the whole economy.

To measure productivity in providing banking services, we used a physical output methodology based on the approach used by the U.S. Bureau of Labor Statistics. This methodology forced us to focus on retail banking. We measured productivity separately in the three key activities of retail banking: transacting payments, managing deposit accounts, and managing loan accounts. Korea has higher labor productivity than the United States in deposits but lower productivity in pay-

38. Industries in which lending was formally banned accounted for 25 percent of the establishments operating in Korea in 1991. 
Table 4. Personal Financial Services Labor Productivity, by Country Index: United States $=100$

\begin{tabular}{|c|c|c|c|c|}
\hline Country & $\begin{array}{l}\text { Transacting } \\
\text { payments and } \\
\text { disbursing cash }{ }^{\mathrm{a}} \\
\text { (number of }^{\text {(numbarions per }} \\
\text { transaction } \\
\text { hour of labor } \\
\text { input) }\end{array}$ & 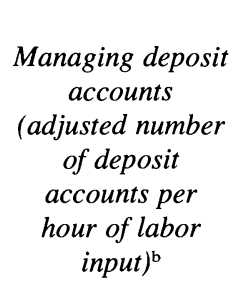 & $\begin{array}{c}\text { Managing loan } \\
\text { accounts } \\
\text { (adjusted } \\
\text { number of } \\
\text { deposit } \\
\text { accounts per } \\
\text { hour of labor } \\
\text { input) }\end{array}$ & Total $^{\mathrm{d}}$ \\
\hline Netherlands (1995) & 140 & n.a. & n.a. & n.a. \\
\hline United States (1994) & 100 & 100 & 100 & 100 \\
\hline Korea (1995) & 65 & 138 & 57 & 76 \\
\hline
\end{tabular}

ments and loans (table 4). ${ }^{39}$ Both Korea and the United States have lower payments productivity than the Netherlands. Overall Korean productivity is 76 percent of that in the United States.

Korean productivity in payments is weak because of a less efficient mix of electronic and manual payments, a denser branch network, and less efficient utilization of labor. The Netherlands makes much greater use of electronic payments than the United States or Korea (table 5); these payments have labor requirements that are two to ten times lower than checks and paper-based transfers. In addition, Koreans conduct a much greater share of payment transactions at the teller. The Netherlands also derives a productivity advantage from its fewer branches per capita, in part because of high population density. Korea also has a high population density, but it has not rationalized its branch network.

After adjusting for the mix of payments and density of branch networks, the United States has the most efficient utilization of labor. U.S. banks aggressively use part-time tellers to avoid the problem of peak demand periods (figure 14). When one U.S. bank increased the share of part-time tellers from 25 to 50 percent, it was able to reduce total full-time-equivalent employees by 20 percent without impairing service

39. Capital input is very difficult to estimate for banks because it is very hard to separate the fixed assets that are used to provide banking services from those that are held as real estate investments. We therefore are limited to measuring labor productivity. 
Table 5. Financial Services Payments, by Country and Type, 1994-95

Percent of total ${ }^{\mathrm{a}}$

\begin{tabular}{lccc}
\hline Type of Payment & Netherlands (1995) & United States (1994) & Korea (1995) \\
\hline Total electronic transactions & 88 & 28 & 31 \\
Paperless credit transfer & 50 & 2 & 7 \\
Direct debits & 18 & 1 & 4 \\
Credit and debit cards & 7 & 16 & 6 \\
Cash withdrawals at ATM & 13 & 9 & 14 \\
Total paper transactions & 12 & 71 & 70 \\
Paper-based credit transfer & 3 & 0 & 9 \\
Checks & 5 & 68 & 27 \\
Cash withdrawal at teller & 4 & 3 & 34 \\
\hline
\end{tabular}

Source: McKinsey Global Institute (1998a, "Personal Financial Services Industry," p. 6).

a. Total number of transactions in millions: Netherlands, 15,838; United States, 90,053; Korea, 3,629.

b. No debit card for Korea in 1995.

quality. Korean banks have less flexible working hours and do not use incentive-based compensation, which further affects productivity.

In lending, Korean branches are managed as a series of little banks. Credit decisions are made in each branch through manual and hierarchical processes. Larger loans also require hierarchical review at head offices. Lending officers cannot be given incentives to sell loans because of their dual responsibility for reviewing credit. They are instead personally penalized for defaults. This leads the officers and branch

Figure 14. Branch Bank Staffing, by Type of Employee, United States and Korea, 1994

Employee composition Percent

Hourly/peak-

\begin{tabular}{l|c|c|c|} 
time employees & 9 & $\cdots$ & $<10$ \\
\cline { 2 - 4 } $\begin{array}{l}\text { Hourly/part- } \\
\text { time employees }\end{array}$ & 24 & $\therefore$ & \\
\cline { 2 - 4 } $\begin{array}{l}\text { Full-time } \\
\text { employees }\end{array}$ & 67 & & \\
& & & \\
& & \\
& $\begin{array}{c}\text { U.S. large } \\
\text { commercial } \\
\text { banking } \\
\text { institutions }\end{array}$ & $\begin{array}{c}\text { Korean } \\
\text { banks }\end{array}$
\end{tabular}

Number of customers; during a month, 1994

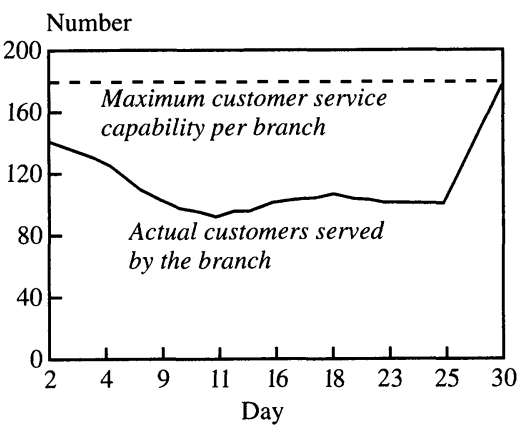


managers to review loan applications in a painstakingly careful manner, which has created a credit approval process that takes days or weeks and requires much more labor. In the United States, banks have centralized lending decisions, allowing branches to focus on selling loans and creating the scale needed to implement credit scoring. This has reduced the time required for lending decisions to minutes or hours, and has reduced labor requirements by up to 50 percent.

Korean banks are productive in taking deposits. The highly regulated banking environment has effectively made increasing deposits the natural focus for banks. As a result, they have streamlined taking deposits while minimizing the amount of advice provided to depositors. Opening an account is done at the teller, directly in the banks' computer systems. All deposit handling is, therefore, as easy as handling transactions.

It is not hard to see the relation between the structure and goals of the banking industry, as influenced by government policy, and the industry's performance. The banks are not intended to encourage spending and borrowing but rather to encourage saving, which is then directed to industrial development.

Competition among the banks is limited. Because interest rates on deposits and loans are regulated, banks cannot compete in payments and lending, but only through branch expansion to gain access to deposits. The government also controls entry to the banking industry, so that specialized competitors, such as Countrywide in the United States, are not able to compete for specific bank activities. (Until recently, securitization of mortgages or consumer loans was also not available.) The exit of poorly performing banks has also been controlled by the government. Strong ties between government and the industry seem to have created beliefs among bank managers and customers that banks will never go bankrupt. Deposit insurance was only introduced in 1996, but in fact no Korean banks have gone bankrupt or merged for the past fifteen years. The only merger in the history of the banking industry (between Seoul Bank and Korea Trust Bank) was led by the government in 1976 .

Unions and labor rules have also affected banks' performance. All Korean banks including the Central Bank are unionized and subject to rules that make layoffs difficult or impossible, restrict flexible staffing, and discourage incentive pay. These practices are also a barrier for mergers and acquisitions because these usually involve layoffs. 


\section{Synthesis of the Results}

Most developing countries would be delighted to have experienced the growth in GDP per capita that Korea experienced from 1970 to 1995. To have mobilized such large amounts of capital and labor and educated its work force at such speed was an amazing achievement. Several of our industry case studies have shown how Korea accomplished the growth. In steel, POSCO purchased plants that incorporated best-practice technology, managed plant construction efficiently, and staffed at best-practice levels. The telecommunications industry created an efficient high-technology network. In the semiconductor industry, Korean companies were able to acquire the engineering knowledge needed to achieve relatively high productivity in DRAMS. By successfully transferring best-practice capital technology, Korea succeeded where many other developing countries did not. ${ }^{40}$

At the same time, the case studies also suggest why the growth in Korea was not achieved with higher productivity.

-Korea has been able to acquire best-practice engineering and technical knowledge but not best-practice managerial knowledge. ${ }^{41}$ It has been able to transfer best-practice technology when the technology has been embodied in capital goods. The country has also successfully acquired engineering knowledge and managed capital building projects. In the case of integrated steel mills, that was enough to create a bestpractice industry. Automotive manufacturing has not been able to transfer the intangible capital (total quality management, continuous improvement, design for manufacturing) required for lean production. The semiconductor industry has not been able to transfer the design skills needed for higher-value-added chips.

40. Our projects on Brazil (McKinsey Global Institute, 1998b) and Latin America (McKinsey Global Institute, 1994a) show how other developing countries have failed to efficiently transfer best-practice capital technology. Unlike POSCO, the steel industries in Brazil, Mexico, and Argentina built small, poorly laid out plants that they dramatically paid too much for (corruption was a major problem) and overstaffed. The same was true in telecommunications.

41. Dollar and Sokoloff (1990) found a different dichotomy. Using 1963-79 data, they found that within manufacturing total factor productivity growth had been high in textiles and other light and medium industries and low in such heavy industries as steel and chemicals. This suggests that as of 1979, Korea had mastered some engineering challenges, but not all of them. We find that by 1995 Korea had acquired the remaining engineering knowledge but still lagged in managerial knowledge. 
It is very hard to transfer certain types of intangible capital. The U.S. auto industry has not caught up to Japanese industry in productivity because it has not fully transferred lean production to all its products and plants. Aside from Intel, profits have been scarce in the semiconductor industry worldwide. As well as its strong design skills, Intel, like Microsoft, has an advantage it inherited from IBM. It sets the industry standard. It is thus not surprising that Korea found it difficult to catch up to best practice in many sectors, particularly when it decided not to allow foreign direct investment.

- Capital has been misallocated within and among industries. Government policy has strongly affected the allocation by controlling or influencing the banks, making funds available to some industries and discouraging borrowing by others. In some cases this worked. In steel the investments earned a high rate of return and (until the crisis) there was no overcapacity. In telecommunications an efficient network was set up. However, in autos, semiconductors, and confectionery, the chaebol's access to funds encouraged overinvestment. Cronyism and outright fraud undermined the efficiency of the government-controlled capital allocation system. In addition, direct industry regulation prevented some profitable investments from being made and distorted others. Regulation prevented investments in modern retailing. In milling, automation investments with very short estimated payback periods were not made because of regulations that inhibited the consolidation of the industry.

Even taking the regulatory environment as given, companies did not always make economically rational decisions. Access to bank lending may have encouraged overinvestment, but the chaebol generally had the owners' funds at risk and still retained an incentive to make wise investments. In practice, we found from interviews and from working with companies that their decisions were based on gaining market share, not on profitability. We have noted the overcapacity in auto manufacturing and the large investments in semiconductors despite very uncertain profit prospects. In confectionery, companies overinvested in new production lines but did not make investments with good payoffs in packaging automation. Banks used information technology much less than would have been justified on profitability grounds.

Our findings about the structure of financial institutions and the misallocation of capital suggest some causes for the financial crisis. The 
crisis had several elements, including an overvalued exchange rate and contagion effects from other Asian economies. But the case studies have revealed some more fundamental problems that made the Korean economy vulnerable.

The reason the crisis in Korea occurred in 1997, instead of earlier or later, is that a crisis in Thailand in 1997 spread to other Asian countries. Crises are often associated with a shortage of liquidity, and this was certainly the case in Korea, where foreign lenders refused to roll over loans because they perceived the risk as being too great. Indeed, some observers have likened the crisis to a speculative panic that spread to different countries in the way that panic selling on the stock market will drag down most or all companies. And there is some truth to this; a shift in investor expectations certainly took place.

But blaming the crisis in Korea entirely on panicky overreaction to events elsewhere in Asia is not plausible. Following the crisis in Thailand, only a handful of countries around the world were forced into crisis. Why some and not others? The crisis in Korea did not occur for some months after Thailand's, and not until there were bankruptcies among the chaebols (most notably Hanbo steel where $\$ 5$ billion was lent to finance a minimill that would have cost $\$ 1.5$ billion in the United States). Certainly, events elsewhere in Asia changed the assessment of risk, but there were deeper problems.

The crisis in Thailand spread because it forced a reappraisal of the risks of lending in East Asia. ${ }^{42}$ Banks in the West and especially in Japan had believed the risk of lending to these countries was very low because of their rapid growth and the support the governments were giving to the banks. Once lenders started looking seriously at the fundamentals, they found severe problems, problems that had in fact existed for some time. A 1994 McKinsey Global Institute study of capital markets reported:

"The case of Korea illustrates the cost of providing large amounts of credit that are not allocated by the market. . . . Directed credit has led to very high levels of non-performing assets in the banking system. In 1993 , Korea had a ratio of non-performing assets to total assets of 10

42. We said earlier that Japan and Korea are on very similar growth paths. Japan may well show how an economy with some of the same fundamental problems in lending and investment decisionmaking as Korea can have a financial crisis without having a liquidity crisis. 
percent, versus just over 1 percent in the United States. . . . Even at the peak of the savings and loan crisis in the United States during the late 1980 s, this ratio was less than 2 percent of total assets. " 43

From a limited number of case studies we cannot prove an argument, but our observations strongly suggest why there were nonperforming loans. The rate of return on capital in many industries had been driven down, and this was not because the overall capital intensity of the economy had become particularly high. Rather it was that capital investment had been concentrated in certain industries so that their capital intensity had reached or exceeded U.S. levels while productivity remained weak. Moreover, even within companies capital use was often poor. Thus capital productivity and the return to capital were low. Specifically, we found in autos, semiconductors, and confectionery that capital intensity was about the same as in the United States but productivity was much lower and the gross return to capital was only one-half to two-thirds that in the United States.

The concentration of investment in export-oriented manufacturing was clearly encouraged by the government, in part through its influence over the lending decisions of banks. Individual lending decisions were politically influenced and in some cases involved outright corruption, as with the Hanbo loan. The careers of top bank officials were determined more by politics than by their lending performance, and bank officers were rotated so frequently that there was limited accountability. These factors made possible companies' poor investment decisions. Properly regulated, profit-maximizing lenders would have demanded that better investments be made.

And yet the entire explanation does not lie with the lenders. The owners of the chaebol that made poor investment decisions had significant amounts of their own money at stake. Although Korea's 1995 debt-to-equity ratio of 3:1 for manufacturers is high compared with the 1.7:1 average for the United States, this still means that owners of Korean companies were contributing 25 percent of the firm's capital. ${ }^{44}$

43. McKinsey Global Institute (1994b, chap. 2, p. 8). Nobody likes the smart aleck that says "I told you so," but in fact we, and no doubt others, did tell them so. There was a Global Institute presentation in Seoul in March 1994 on problem loans.

44. The companies that went bankrupt recently (among them Hanbo, Sammi, Jinro, and Kia) were probably more highly leveraged than average when they made their illfated investment decisions and thus more prone to moral hazard. But investments with 
It is hard to see how it was in their interests to overinvest just because banks were willing to lend them the money. Furthermore, with the important exception of DRAM manufacturing, most of the overinvestment does not appear to have involved gambles that went wrong. It is hard to see how investments involving excessive product proliferation in processed food and those focusing on volume instead of quality in the automotive industry would have paid off even in a Panglossian world. And even though the focus on DRAM chips was a gamble, the companies involved had substantial equity in other businesses, which they were putting at risk.

If Korean companies had such a strong incentive to make good investment decisions, why were their decisions so bad? One culprit is the absence of capital management skills. Measures such as return on invested capital and economic value added were not used by Korean firms. Financial statements tracking the true contributions and returns earned by individual subsidiaries, business units, and products were not available, even internally. Few companies measured their operational performance, especially their capital productivity, against best practice.

The high-growth environment in Korea from the 1960s through the 1980s reduced the need for these management techniques and thus crippled the incentive to acquire them. If capital could be obtained from banks (often at negative real interest rates), it was not hard to find a profitable investment. Overcapacity problems were solved with a few years' growth, and land appreciation was rapid enough that even otherwise uneconomic investments could be justified on the grounds that they created an excuse to speculate in land. At the same time that capital availability increased in the 1990 s, the conditions that had helped make investments profitable changed: land appreciation ended in 1991, and GDP growth slowed in 1996.

\section{Alternative Growth Paths}

These results raise two important questions. First, could Korea have grown as fast or faster if it had adopted a different development strat-

low returns were made by almost every large Korean firm, including the most financially sound. 
egy? Second, what should it do to enhance its growth prospects? We have some thoughts on the first of these questions, but not a clear answer. We believe that there is a clear answer to the second question, however. We estimate Korea's future growth potential under different policy approaches.

\section{Reviewing the Past}

Korea has followed the Japanese path of input-driven growth with long hours of work, high rates of saving with funds channeled into the industrial sector, a strong export orientation, strict limits on "nonessential" 'imports and direct foreign investment, and strict zoning laws and other restrictions on the distribution system. These characteristics describe both economies' approach to development. ${ }^{45}$

This path carries penalties for productivity, illustrated by Korea's experience.

- Limiting direct foreign investment forces domestic industries to attempt to master best-practice technologies on their own. For best practices in the automotive industry (lean production), semiconductors (design of non-DRAM chips), processed food and telecommunications (marketing, capacity management), and banking (credit risk assessment), this has proven very difficult.

-Channeling funds into priority sectors is easy to overdo. Industrial policy and government control of bank lending may be helpful in the early stages of economic development, particularly when capital markets are undeveloped. Whether or not this is the case, Korea retained a directed approach too long and overinvested in favored industries while restricting or discouraging investments elsewhere.

-Exposure to best-practice competitors can be beneficial. In earlier work for the McKinsey Global Institute we found that exposing companies to best-practice competitors encourages them to be more productive. Limiting foreign competition in Korea meant that many domestic companies did not feel the pressure to be more productive.

Although we suspect that Korean consumers would have been better

45. There are of course differences between the two economies. Japan developed its own first-rate capital goods industry, reducing the import requirements for growth. It also has large foreign exchange reserves and has avoided a currency crisis, although it is facing a banking crisis. 
off with a less restrictive policy environment, we do not have enough evidence to replay Korea's history. We do not know whether the long hours of work and the high savings could have been mobilized in a more open and consumer-oriented economy. We do not know whether more direct foreign investment or imports competing against infant industries would have encouraged greater productivity or have led to infanticide.

\section{Alternative Growth Policies for the Future}

In this section we describe alternative growth scenarios that Korea might achieve under different policy regimes. We take 2000 as our starting point, with the idea that the current crisis will have passed by then and that reform legislation could have been implemented. ${ }^{46} \mathrm{We}$ estimate the growth potential for ten years through 2010 .

We are not making forecasts, and we have excluded many important variables, such as monetary and demand-side variables, as well as social factors. The main novelty and contribution of this exercise is to use the case study results and McKinsey's knowledge of industries worldwide to make rough estimates of potential labor productivity growth. In the alternative scenarios we assess the extent to which alternative policies would or would not allow this potential to be realized. We are not looking for precise estimates but rather a quantitative judgment as to whether policy differences are significant. Given space constraints we cannot do justice to the material. Readers are referred to the full Korea report. $^{47}$

The policy scenarios we examined follow.

-Scenario 1: Assumes no fundamental reform and that the government continues to be a significant factor in directing economic development. We estimate that GDP per capita growth would drop to 3 percent a year, and Korea would remain vulnerable to another financial crisis. This growth path would represent a continuation of the Japanese path, where per capita growth dropped from 7.5 percent in 1964-74 to 3 percent in 1974-84.

46. Using 2000 to start gives us a dilemma because the most recent actual data we have is for 1995. Therefore, we simply assume that the state of the economy that existed in 1995 prevails in 2000 . To the extent that this is not true, our estimate of the future would have to be adjusted.

47. McKinsey Global Institute (1998a). 
-Scenario 2: Assumes the financial and manufacturing sectors are reformed but not services and construction. We estimate that growth would be higher, at 4 percent a year for GDP per capita, and that the risks of another financial crisis would be averted. Employment in manufacturing would decline by about 20 percent over ten years as firms faced competitive pressure. However, there would be a lack of good jobs opening up in services, so workers would be forced either into low-productivity or subsistence employment.

- Scenario 3: Assumes reforms to services and construction as well as manufacturing. We estimate that per capita growth could be as high as 6 percent and that services would provide employment opportunities for displaced manufacturing workers. Manufacturing growth would actually be higher than under scenario 2 because the greater income growth generated in services would increase the demand for manufactured goods.

Our first step then was to figure out the growth potential in each of the case study industries under different policy regimes. In no case did we assume new technologies or formats were developed. Instead, we examined the likely diffusion of best practices. More specifics are given later and in the McKinsey Global Institute report, but the idea was to use the experience of other countries to see how rapidly diffusion occurs in a less regulated environment and then modify this to reflect different factor endowments of land or skilled labor. In scenarios 1 and 2 we estimated how continued restrictions would slow this diffusion process. Using the cases as a guide, we then extrapolated to the broader sectors of the economy to estimate potential productivity growth by broad sector of the economy. ${ }^{48}$

To move from potential productivity growth by sector to overall growth requires an estimate of how expenditure is allocated by sector as income growth proceeds. In a general equilibrium exercise, estimating income and price elasticities for the outputs of the different industries could do this. Instead, we took a simpler approach and looked at current and historical data on the distribution of output by industry in other countries as they passed through the levels of income that Korea

48. Real GDP in 2010 is measured in 2000 (actually 1995) relative prices (except for semiconductors). This means that even if one of our scenarios were to play out exactly as described, the actual measured growth 2000-2010 would be slower than the rates given here. 
would reach in each scenario. We then used this historical experience to provide a benchmark for the likely changes in Korea's distribution of output as it grows. In doing this we recognized that Korea's emphasis on heavy industrial development will affect its future even if the policy environment changes. In short, Korea will not look exactly like the United States looked at a similar level of income.

The level of aggregate labor input is based on current forecasts of labor force growth plus an assumption that hours per worker decline by 1 percent a year, as occurred in Japan when its income reached comparable levels. Given the productivity estimates and the output distribution, there is an implied distribution of employment.

One approach on the capital input to growth would be to estimate the likely saving rate in Korea and thus the availability of capital. We took a different approach. We made estimates of the capital requirements for each sector of the economy, taking into account, for example in retailing, the investment in new construction needed as modern retail formats are introduced. This may miss some nuances of capital-labor substitution as factor prices change, but it draws on the pattern of investment seen historically elsewhere. We then aggregated up to an estimate of the amount of capital required in each of the growth scenarios. We assumed that this much capital will either be available through domestic saving or foreign borrowing. If too much saving is available, it will flow into foreign lending. ${ }^{49}$

To illustrate the approach, we look at the specifics for scenario 3 . We then summarize how scenarios 1 and 2 differ. ${ }^{50}$ Table 6 illustrates the estimates made of the potential for growth in the case study industries. The exhibit shows where the industry would stand relative to the United States in 2000, where it would reach in 2010, and the implied growth rate over time.

McKinsey has detailed knowledge of all the major steel plants around the world. The nature of best practices in each element of steelmaking can be assessed. The 5 percent growth assumed for the Korean industry is in line with the rate of increase this industry has achieved in the recent past. In scenario 3 we assume that productivity is increased in

49. In a similar study on Brazil we also examined the foreign exchange and skill requirements for growth. In Korea our judgment was that these factors should not constrain growth.

50. Additional detail can be found in McKinsey Global Institute (1998a). 
Table 6. Estimated Labor Productivity Growth, by Selected Industry, Scenario 3 Index: U.S. 1995 productivity $=100$

\begin{tabular}{lccc}
\hline Industry & Level in 2000 & Level in 2010 & $\begin{array}{c}\text { CAGR } \\
\text { (Percent) }\end{array}$ \\
\hline Steel & 108 & 180 & 5 \\
Automotive & 48 & 120 & 10 \\
Confectionery & 43 & 110 & 10 \\
Wet corn milling $_{\text {Semiconductors }}^{\mathrm{a}}$ & 24 & 100 & 15 \\
Telecommunications $_{\text {Retail banking }}$ & 52 & 70 & 3 \\
Housing construction & 64 & 120 & 7 \\
Retail & 76 & 120 & 5 \\
Average & 69 & 100 & 4 \\
\hline
\end{tabular}

Source: McKinsey. CAGR means compound annual growth rate.

a. Five-year forecast

this industry by greater competitive pressure on the minimills that results in improved product mix and increased automation. In the automotive industry, direct foreign investment by best-practice competitors and the spread of best practice as a result of more competition should encourage the industry to maintain 10 percent productivity growth for ten years ahead. At that point it would still be well below where the Japanese industry is likely to be in 2010 . In confectionery we assume direct foreign investment improves operational efficiency and marketing. It forces a rationalization of the product range and of plants. In wet corn milling, competition is assumed to cause industry consolidation around two large plants (compared with fifteen currently). In semiconductors we assume that the Korean industry does not try to move into more advanced chips. Instead, the weaker DRAM manufacturers exit the industry. ${ }^{51}$

In telecommunications the main improvement results from increased utilization as privatization brings greater emphasis on marketing and overall incomes increase. In retail banking it is assumed that the industry moves toward electronic funds transfer and that specialized players introduce higher-value-added products. Both construction and retailing evolve as a result of opening up zoning and the ability of the industries

51. In the semiconductor case we use Bureau of Economic Analysis deflators, which imply massive productivity growth for both the U.S. and Korean industries. The 3 percent growth reported here is relative to the U.S. level of productivity. 
Table 7. Estimated Labor Productivity Growth, by Sector, Scenario 3 Index: U.S. 1995 productivity $=100$

\begin{tabular}{lcccc}
\hline & Level in 2000 & Level in 2010 & $\begin{array}{c}\text { Last 10-year } \\
\text { CAGR } \\
\text { (Percent) }\end{array}$ & $\begin{array}{c}2000-10 \\
\text { CAGR } \\
\text { (Percent) }\end{array}$ \\
\hline Pggregate sectors & 30 & 70 & 4 & 9 \\
Business services & 40 & 70 & 1 & 6 \\
Utilities and transportation & 55 & 100 & 7 & 6 \\
Trade & 30 & 70 & 4 & 9 \\
Construction & 60 & 100 & 3 & 4 \\
Manufacturing & 40 & 85 & 7 & 7 \\
Agriculture & 15 & 30 & 5 & 7 \\
Total & 36 & 73 & 6 & 7 \\
\hline
\end{tabular}

Sources: OECD; McKinsey. CAGR means compound annual growth rate.

to attract funds. The construction industry builds more single-family homes and higher-value-added multifamily homes. Retailing moves to a combination of discounters and high-service formats

Table 7 shows the estimated extrapolation to the broader sectors of the economy. The potential growth in personal services and wholesale and retail trade were both assumed to be similar to that in the retail trade case. Growth in business services was taken from the retail banking case. Utilities and transportation were assumed to reach the 1995 U.S. level by 2010 . The results from the telecommunications case were used as a guide in setting this assumption. Growth in construction was based on the housing construction case, while the manufacturing cases were used as the guide to potential growth in overall manufacturing. Productivity growth in agriculture was assumed to be more rapid than in the past because of the pull of workers out of this sector, with rapid employment growth in services occurring under scenario 3 .

Figure 15 shows the predicted distribution of output if the productivity growth by sector given in table 6 is realized. This implies an 80 percent increase in GDP per capita over the ten years and would put Korea at about the same level as the United States was in 1988. We explored the output distributions of a variety of countries and found enough similarity in the pattern that we felt confident in using an adjusted U.S. distribution as the benchmark for this scenario. We adjusted the assumed 2010 Korean distribution away from the 1988 U.S. output distribution because of the starting point, giving a somewhat larger 
Figure 15. Per Capita Output Growth Potential, Korea Scenario Three

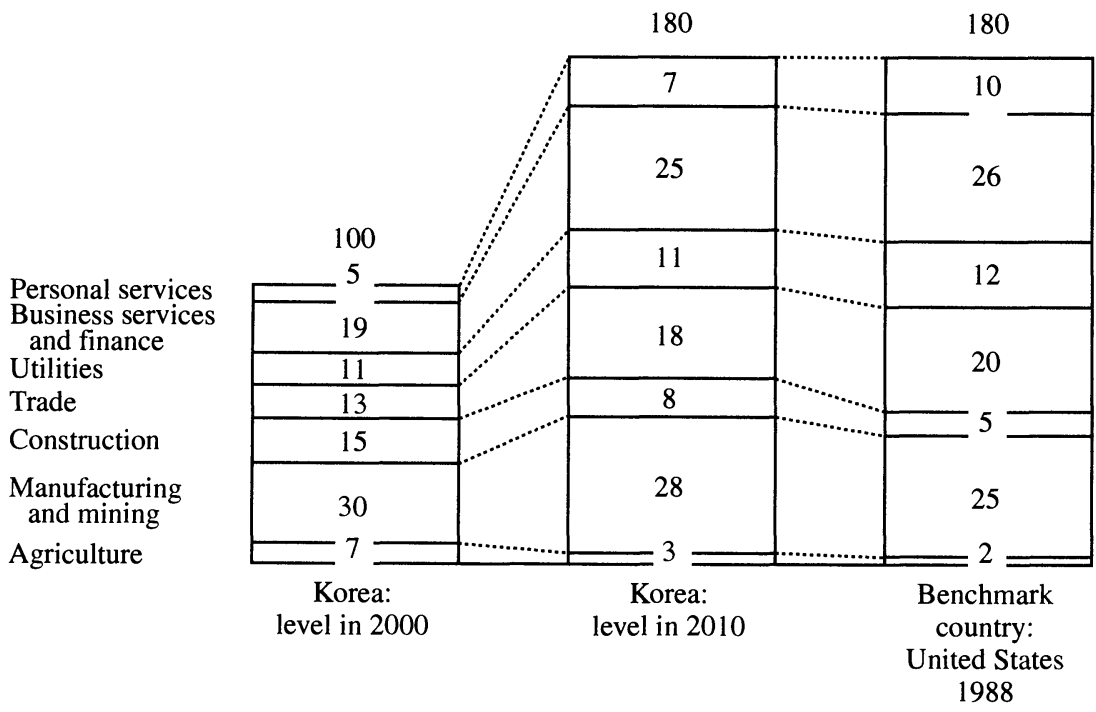

Index: Korean GDP $=100$ in 2000

Sources: Organization for Economic Cooperation and Development; and McKinsey. Based on nominal GDP shares in relative prices of the initial period.

share of output to agriculture, manufacturing, and construction and correspondingly smaller shares to the remaining sectors.

Table 8 shows the assumption made about capital productivity (the output-capital ratio). We suggest that capital productivity on average would stay the same in the economy, at slightly above the U.S. level. This reflects the increase of output per unit of capital in the manufacturing and industrial sectors, where there has been overinvestment and misallocation, and the decrease in service sectors where there has been underinvestment.

Table 8. Estimated Capital Productivity Estimate by Sector, Scenario 3

Index: U.S. $1995=100$

\begin{tabular}{lcc}
\hline Sectors & Level in 2000 & Level in 2010 \\
\hline Manufacturing and utilities & 80 & 100 \\
Services sectors & 150 & 110 \\
Total & 105 & 107 \\
\hline
\end{tabular}

Sources: OECD; McKinsey. 
Figure 16. Korean Investment Requirement, Capital Stock per Capita

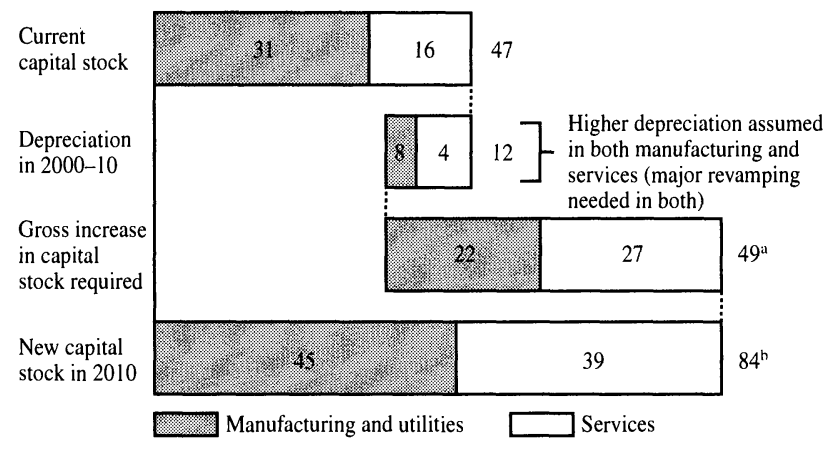

Index: United States $1995=100$

Sources: Organization for Economic Cooperation and Development; and McKinsey.

a. Thirty percent investment rate required (18 percent business investment rate). Investment in residential housing (8 percent of GDP) and government investment (4 percent of GDP) are assumed to remain constant.

b. Based on generalization of capital productivity estimates.

Figure 16 translates these findings into an investment rate, taking depreciation into account. There is a dramatic shift in the location of the capital implied in these numbers. Whereas the current business capital stock is split roughly two-thirds manufacturing and one-third services and construction, the 2010 stock is split close to half and half. The business investment rate required for this scenario is 18 percent of GDP; more than half of the new investment would be in services and construction. The overall investment rate would be around 30 percent.

The message from scenario 3 is fundamentally positive. We find that Korea has the potential to increase its GDP per capita by 80 percent over ten years. It has the ability to absorb large additions to its capital stock without running into diminishing returns. Indeed it needs to maintain a very high investment rate to realize its potential for growth.

This does not mean that Korea will actually follow this path. It may find that its saving rate falls once regulations on the economy are lifted. It may decide not to attempt such a comprehensive program of deregulation. It may run into political conflict as some companies shed workers-indeed, this has already happened. Scenarios 1 and 2 provide our estimates of what might happen with less reform.

If there is no fundamental change in Korea (scenario 1), we would 
expect much slower growth. In manufacturing, productivity growth slows sharply in the capital-intensive sectors as the gains from investing in leading-edge equipment are exhausted. ${ }^{52} \mathrm{We}$ assume that productivity growth in large labor-intensive industries that we did not study explicitly, such as apparel and light electronics, would continue at about their recent growth rate. Overall we would expect manufacturing productivity growth to be 4 percent a year. For similar reasons, banking productivity growth would slow as investment opportunities are filled within an unchanged industry structure. Continued tight zoning laws would restrict the development of more productive retailing and residential construction industries.

Extrapolating to the broader economic sectors, we estimate that the potential for labor productivity growth in the market economy as a whole is 4 percent a year. That is not bad compared with the growth of economies at the leading edge. There would still be some catch-up going on. But it is well short of the potential with comprehensive reform.

Without any change in the environment, capital productivity would continue to fall, from 5 percent above the current U.S. level to 15 percent below it. With declining capital productivity and declining growth of output, the business investment share of GDP required for this scenario is very high, around 20 percent. The overall investment share would then be 32 percent. To avoid confusion resulting from everything changing at once, we keep the path of labor input the same as in scenario 3, even though income growth is lower. By 2010, GDP per capita would be 35 percent above its starting level, an increase of 3 percent a year.

Although we describe the specifics of this "no change" scenario, we believe that it may not be feasible. Very high investment levels would continue despite falling returns to capital. The chances of another financial crisis would be considerable. And given that there has already been one crisis, savers might be unwilling to provide the capital to continue in the same way. It may not be possible for Korea to go as far down the Japanese path as Japan did.

If there were reforms of the financial and manufacturing sectors but

52. Industry by industry specifics are given in McKinsey Global Institute (1998a). In the case of semiconductors, we assume that Korean companies will try unsuccessfully to move into higher-value-added chips. 
no reforms in services and construction (scenario 2), the outcome would be both better and worse than in scenario 1 . There would be more productivity growth in manufacturing (we estimate 6 percent a year) as greater openness, combined with improved lending procedures, would result in more transfer and adoption of best managerial practice and less misallocation of capital. And there would be more productivity growth overall (at 5 percent compared with 4 percent). With less wasteful capital spending, capital productivity would remain stable, and the share of business investment in GDP would fall to 15 percent. The total investment share would be 27 percent. This scenario has the largest share of GDP available for consumption or for net foreign investment.

These figures are calculated on the assumption that the level of labor input that applied to the other scenarios-unemployment at about 5 percent-remains the same. However, the release of labor resulting from increases in manufacturing productivity would be substantial. With growth in modern services choked off by regulation, workers would be forced either into agriculture or low-productivity services, notably retailing formats such as stalls, kiosks, and street markets.

In practice, labor input in this scenario might not be comparable to that in scenarios 1 and 3 . Instead, unemployment might rise. If there were increases in unemployment insurance and other transfers to the point that the available low-wage jobs became unattractive, or if minimum wage rates made such jobs unavailable, workers released from manufacturing or new entrants to the labor force would remain unemployed.

The lesson that we draw from the three scenarios is that comprehensive reform is by far the most attractive policy option. It allows the country's growth potential to be realized. It reduces the chance of another crisis. It creates new employment opportunities and pulls workers out of subsistence agriculture. The alternatives run the risk of either allowing a new crisis or creating increased underemployment or unemployment.

\section{Conclusion}

We find four main lessons from this microeconomic approach to understanding industries in Korea. 
-Korea's rapid growth has included a mixture of successes and failures, with a distinct pattern to the different outcomes. In integrated steel, telecommunications, and DRAMs Korean industries were successful in purchasing and efficiently operating best-practice capital technology. In this respect, Korea succeeded where other developing countries such as Brazil had failed. Korea was less successful in acquiring the design, marketing, and organizational practices essential to high productivity in the automotive, processed food, and banking industries. And even in the "success" industries of semiconductors and telecommunications, the lack of design and marketing skills was a constraint on performance. To some extent this problem occurred because acquiring design and managerial skills is difficult, but it was made more difficult by Korea's strategy of self-reliance and restrictions on foreign direct investment.

- Low productivity and low returns contributed to the crisis. Although other macroeconomic factors no doubt contributed, Korea's recent economic crisis is at least partly due to the low returns that resulted from the low productivity and concentration of capital in manufacturing. Thus we agree with Paul Krugman's view that despite Korea's low overall capital-labor ratio, rapid investment and declining capital productivity helped cause the crisis. ${ }^{53}$ We would disagree, however, at least for Korea, with his attribution of overinvestment to a moral hazard problem involving uncapitalized borrowers with nothing to lose from making risky investments. We found numerous examples of poor investments made by companies with substantial equity interest.

-Korea needs comprehensive reform to encourage a return to rapid growth. Regulation that protects health and safety, encourages competition, and deals with externality problems can work to make markets more efficient. The case studies of Korean industry identified more intrusive and distorting forms of regulation that have caused a misallocation of resources and prevented the productive evolution of industries.

In all the countries we have studied, economic growth involves a decline in agricultural employment and at a certain point a decline in the share of employment in manufacturing. If Korea is to continue to grow rapidly, it must open up the nonagriculture and nonmanufacturing

53. Krugman (1998). 
part of the economy, particularly services. This would create new jobs and new investment opportunities. Unless restrictions are lifted in services, particularly land use restrictions, the rise of productivity in manufacturing and formal agriculture will release labor that will either become unemployed or will be forced into subsistence activities.

-Opening up the economy to international trade and investment will encourage reform in banks and companies and will transfer skills. Korea appears to have suffered from an unfortunate coincidence. It deregulated its capital markets and increased the availability of capital at precisely the time at which a slowing of growth and of the inflation of land prices made profitable investing much less automatic. To resolve this problem, bank loan officers must be trained in loan assessment skills and evaluated on the basis of how well their portfolios perform. Business managers must move away from the goal of maximizing market share and instead use cost and profitability as criteria for success. How are these things to be accomplished? Legal and regulatory frameworks can do much. A crucial mechanism, however, is to force domestic companies to compete against international best practice.

\section{Appendix}

Our methodology for measuring total factor productivity at both the aggregate and industry levels was to assume a Cobb-Douglas net production function with factor shares reflected by the shares of labor cost and gross return to capital (EBITDA) in value added. For the aggregate we excluded both GDP and capital input associated with residential real estate. Output and labor and capital input were measured as follows.

We made cross-country output comparisons either by converting value added to a common currency using an industry purchasing power parity or by using a single or composite physical measure of output. For the aggregate, as well as for automotive, processed food, semiconductor, retail, and construction industries, we used the approach of value added at PPP. The PPPs for the aggregate and construction were from the UN International Comparisons for 1985 updated using national deflators. For processed food we constructed our own PPP by surveying prices in supermarkets in both the United States and Korea, then adjusting the prices for distribution margins and taxes to get a factory- 
gate PPP. For the automotive industry, we used census data on the value of factory shipments and number of vehicles shipped to estimate the average factory-gate price of a car, and then adjusted for size, content, and quality to get the average price of a comparable car. Our quality adjustment came from comparisons of the U.S. prices of comparably sized and equipped U.S., Japanese, and Korean cars. Semiconductors are a global commodity. Our industry practice claimed that domestic prices of semiconductors do not differ from world prices, so we used the average market exchange rate as a PPP.

In banking, telecommunications, and steel, we used physical output measures. In steel we weighted the tons produced of individual products by the average value added per ton of that product, then adjusted for cross-country differences in the extent of vertical integration. For banking we used a methodology based on one developed by the U.S. Bureau of Labor Statistics. We measured the number of payments transacted and deposit and loan accounts maintained and weighted the number of accounts using industry estimates of their labor intensity. We then calculated separate productivity measures for the employees in the three functions and calculated overall productivity weighing by the employment share of the country in the numerator of the functional productivity measures. This produces the same result as if we had weighed the three functional outputs using their labor requirements in the denominator country. ${ }^{54}$

In telecommunications we used a similar approach for measuring labor productivity. Eighty-five percent of telecommunications labor requirements are driven by network size and 15 percent are determined by call volume. So our labor productivity measure is close to access line per hour worked. In contrast, almost all telecommunications capital is used to produce calls, not maintain access lines. So our capital productivity measure is call minutes per unit of capital stock, which can be decomposed into call minutes per line (network utilization) and lines per unit capital stock.

Labor input was simply hours worked. As was discussed in the aggregate analysis, we did not adjust for years of schooling.

We measured aggregate and industry capital input using a perpetual inventory method (PIM) with sudden death depreciation and standard-

54. See Baily and Zitzewitz (1998) for details. 
ized asset lives for all countries. The asset lives for the aggregate were forty years for structures and fifteen years for equipment. For industries we estimated asset lives based on interviews and industry knowledge. In banking and construction we were unable to calculate capital input because we could not separate assets used in the production process from those held by producers as investments. In steel we had access to a proprietary McKinsey database containing information on all steel capital equipment in the countries studied that allowed us to value the steel assets at current replacement costs. This database yielded results similar to a PIM for the United States and Korea, but yielded a lower result for Japan, probably because it correctly captures the retirement of excess capacity in Japan since the early 1970s. 


\section{References}

Amsden, Alice H. 1998. Asia's Next Giant: South Korea and Late Industrialization. Oxford University Press.

Baily, Martin Neil, and Eric Zitzewitz. 1998. "Service Sector Productivity Comparisons: Lessons for Measurement." NBER-CRIW conference paper. National Bureau of Economic Research, Cambridge, Mass.

$\rightarrow$ Benhabib, Jess, and Mark M. Spiegel. 1994. "The Role of Human Capital in Economic Development: Evidence from Aggregate Cross-Country Data." Journal of Monetary Economics 34 (October): 143-74.

Bils, Mark, and Peter J. Klenow. 1998. "Does Schooling Cause Growth or the Other Way Around?' NBER Working Paper 6393. National Bureau of Economic Research, Cambridge, Mass.

$\rightarrow$ Collins, Susan M., and Barry P. Bosworth. 1996. "Economic Growth in East Asia: Accumulation versus Assimilation." Brookings Papers on Economic Activity 2: 135-91.

Corsetti, Giancarlo, Paolo Pesenti, and Nouriel Roubini. 1998. "What Caused the Asian Currency and Financial Crisis?" Unpublished manuscript, Yale University.

$\rightarrow$ Dollar, David, and Kenneth Sokoloff. 1990. "Patterns of Productivity Growth in South Korean Manufacturing Industries, 1963-1979." Journal of Development Economics 33 (October): 309-27.

Hall, Robert E., and Charles I. Jones. Forthcoming. "Why Do Some Countries Produce So Much More Output than Others?' Quarterly Journal of Economics.

Kim, Dae Jung. 1996. Mass Participatory Economy: Korea's Road to World Economic Power. Latham, Md.: University Press of America.

$\rightarrow$ Kim, Jong-Il, and Lawrence J. Lau. 1994. "The Sources of Economic Growth of the East Asian Newly Industrialized Countries." Journal of the Japanese and International Economies 8 (September): 235-71.

Kim, Linsu. 1997. Imitation to Innovation: The Dynamics of Korea's Technological Learning. Harvard Business School Press.

Krugman, Paul. 1998. “What Happened to Asia?' Unpublished manuscript, MIT.

Lee, Seung Jung. 1997. "The Financial Crisis in Korea." Unpublished manuscript cited in Corsetti, Presenti, and Roubini.

McKinsey Global Institute. 1992. Service Sector Productivity. Washington, D.C.: McKinsey \& Co. \& Co.

. 1994a. Latin American Productivity. Washington, D.C.: McKinsey

1994b. The Global Capital Market: Supply, Demand, Pricing, and Allocation. Washington, D.C.: McKinsey \& Co. 
1997. Boosting Dutch Economic Performance. Washington, D.C.: McKinsey \& Co.

- 1998a. Productivity-led Growth for Korea. Washington, D.C.: McKinsey \& Co.

- 1998b. Productivity-The Key to an Accelerated Development Path for Brazil. Washington, D.C.: McKinsey \& Co.

Pack, Howard. 1993. "Industrial and Trade Policies in the High-Performing Asian Economies." Background paper for World Bank, The East Asian Miracle.

Pilat, Dirk. 1994. The Economics of Rapid Growth: The Experience of Japan and Korea. Aldershot, U.K.: Elgar.

Radelet, Steven, and Jeffrey Sachs. 1998. "The Onset of the East Asian Financial Crisis." Unpublished manuscript, Harvard University.

World Bank. 1993. The East Asian Miracle: Economic Growth and Public Policy. Oxford University Press.

$\rightarrow$ Young, Alwyn. 1994. "Lessons from the East Asian NICs: A Contrarian View." European Economic Review 38 (April): 964-73.

$\rightarrow-.1995$. "The Tyranny of Numbers: Confronting the Statistical Realities of the East Asian Growth Experience." Quarterly Journal of Economics 110 (August): 641-80. 


\section{Comments}

Comment by Barry Bosworth: This paper has two major objectives. First, it uses some industry-level data and case study work of McKinsey and Co. to extend the macroeconomic framework of growth accounting Second, it seeks to provide some insights into the causes of the 199798 economic crisis and the policies needed for recovery. The industrylevel analysis is a major extension of previous studies of Korean economic growth. It takes a more negative view of Korea's accomplishments in arguing that although the overall rate of capital investment has been very high, significant portions have been misallocated with a resulting large decline in the rate of return. I was less convinced by the second argument that the declining return to capital was a major cause of the economic crisis.

Previous studies, based on aggregate data, concluded that despite the extraordinarily high rates of economic growth achieved in Korea over the past quarter century, the contribution of gains in total factor productivity (TFP) has been surprisingly modest. Instead, the growth in output per worker has resulted primarily from rapid increases in capital per worker. The emphasis on capital formation as the primary source of growth and the modest contribution of TFP are surprises because one would think that countries that begin with levels of technology far below best practice would find it easier to concentrate on copying the technologies of more advanced economies. Capital accumulation, in contrast, is hard work-it requires sacrifices of foregone consumption that are not easy to achieve in poor societies. In addition, the stress on capital formation would not appear to be sustainable because ultimately it will drive down the rate of return.

Baily and Zitzewitz argue that the emphasis on capital accumulation 
has already reduced the rate of return to capital to a low level that threatens future growth prospects. In addition, they maintain that the low rates of TFP growth are reflective of structural problems that have distorted the allocation of capital. Those same structural problems contributed to the economic crisis. The conclusion is that comprehensive economic reform is a precondition for a return to high growth in the future.

A major strength of this paper is the measurement of outputs and capital inputs in comparable international prices. This makes it possible to make cross-national comparisons of the level, as well as the rate of growth, of labor productivity and TFP. For example, Korea has about the same level of total inputs (capital plus labor) per capita as the United States, but it generates only about half the level of gross domestic product. The mix of inputs is also quite different as Koreans work longer hours than Americans, but the amount of capital per worker is still well below the U.S. standard. The comparisons with Japan and the United States suggest that Korea has been able to obtain best-practice capital and technology on international markets at competitive prices, but it has been far less successful in applying best-practice management skills.

The microeconomic analysis of eight Korean industries reinforces the conclusions of the aggregate analysis in finding consistent evidence of modest gains in TFP, but it goes beyond that research in documenting cases of poor investment choices. Levels of capital per worker in some industries are close to the U.S. levels, but the corresponding estimates of TFP lag far behind. Some of the results, however, contrast sharply with conventional wisdom. The government-owned integrated steel mills appear to be world class, whereas the privately owned minimills are quite inefficient. Similarly, the telecommunications industry is still dominated by a state-owned firm, yet it has a relatively efficient network. The number of access lines per worker is comparable to the United States, but the utilization of those lines is far below that of the United States. The authors trace the difference to the reliance on per minute pricing of local calls in Korea compared with fixed monthly rates in the United States-Koreans spend much less time on the telephone than do Americans.

I do have some reservations about the results, however. The microeconomic extensions do raise a question of whether they are represen- 
tative of Korean industry as a whole. How were they chosen? Are these simply industries for which past studies of McKinsey and Co. had developed data? Certainly they do not represent balanced samples of the overall economy. Second, microeconomic studies have difficulty fitting the analytical framework of the aggregate analysis with the data available at the industry level. Information on investment and the capital stock is particularly limited at the level of individual firms and industries.

In addition, I would question the emphasis placed on measures of output per unit of capital, that is, capital productivity. Many past studies have focused on labor productivity because of its close link to real wages and living standards. Also, the change in output per worker can easily be partitioned between the two critical components of the growth process: the contribution of increased capital per worker, and gains in TFP - the efficiency with which the inputs are used. The same logic does not apply to the concept of capital productivity. The general message of the paper is that capital is poorly utilized in Korea as measured by the low average ratio of output to capital. But, by that same measure, the productivity of capital is estimated to be higher in the service sectors of Korea than in the United States (see the authors' figure 4). The scarcity of capital in the service sector should not be interpreted as evidence of efficiency in its use. If a measure of capital is available, it seems preferable to focus on changes in TFP and the amount of capital per worker, and not on the ratio of output to capital.

Finally, the authors place great emphasis on a low return to capital in Korea as evidence of excessive reliance on capital formation. However, although the OECD data they cite show a decline from a very high level in the mid-1980s, the rate of return is still comparable to that in other industrial countries. During the same period, the real return on debt instruments has remained basically unchanged, suggesting a large decline in the risk premium in Korea. That should be seen as a positive development. Korea cannot sustain its high growth in the future by relying on growth in the capital stock that exceeds growth of output without driving the rate of return to low levels; but that return is not yet at a crisis point. Capital per labor hour in Korea is still only about a third of that of the United States and Japan.

Korea does have a very high ratio of debt to equity, but that is an inevitable consequence of its extraordinarily high growth. Individual 
enterprises cannot finance high growth solely out of internal funds. Yet, in all countries debt, not equity, issues are the dominant source of external finance. The debt-equity ratio is low only in countries with relatively low growth rates, such as the United States, that have only limited need for external finance.

I am particularly doubtful that the falling rate of domestic profit and a loss of investor confidence played a major role in Korea's economic crisis. The economy was growing rapidly in the months before the currency collapse, and there was little evidence of investor concern in financial markets. The suddenness of the collapse is more reflective of a liquidity crisis triggered by the crises in other parts of Asia. Korea had an extraordinarily low level of reserves relative to its short-term foreign liabilities. The exchange rate collapse initiated in turn a sharp fall of domestic demand; and when the government increased interest rates in an effort to support the exchange rate, highly leveraged enterprises went into default on their loans, bringing down the banking system. The crisis and subsequent recession seem much more reflective of failures in the financial system than the real sector.

Comment by Larry E. Westphal: This is a particularly timely and especially valuable contribution to our understanding of the performance and prospects of the Korean economy. ${ }^{1}$ The authors have given us a unique perspective on Korean development, one derived from painstaking and carefully conducted microeconomic empirical work of the sort that one wishes could more often be done for diagnostic purposes as well as to inform theoretical analysis. I have no reason whatsoever to doubt the essential validity of the findings with respect to the TFP (total factor productivity) levels and growth rates of the industries studied, or to question the detailed portrayals of their comparative strengths and weaknesses. Of course, one might reasonably wish that the sample of industries were more diverse-for example, that other important manufacturing industries having somewhat different characteristics, such as textiles, had been sampled. But one has to agree that the sampled industries include several that have been considered key to Korea's success in the manufacturing realm, certainly by those commentators who have lauded Korea's approach to development.

1. Thanks are due to Howard Pack for helpful reactions on the draft of these comments. 
The authors motivate their analysis by asking if the economies of East Asia "need to undertake fundamental economic reform to resume a path of strong economic growth?' Their answer, for Korea at least, is a resounding "Yes." In support of their answer, they marshal a considerable body of evidence pointing to allocative and managerial deficiencies, and they deploy alternative policy scenarios that suggest the need for major changes in development strategy and economic policy. Although the evidence surely compels agreement that there is substantial scope for improving the productivity of the Korean economy, the scenario analysis is, to my mind, at best only weakly suggestive for those who were not a party to its construction. I will accordingly have nothing further to say about it. Rather, I will focus my comments on the context in which the authors place their analysis. Although I concur with the view that major reforms are warranted, I do not agree with the authors' principal arguments in support of this conclusion.

The context of the authors' analysis is decidedly neoclassical. This is clear from its general tenor as well as from the judgments made in relation to specific findings about the impact of various government policies in the promotional and regulatory spheres. The pursuit of more liberal policies would, in the authors' view, have avoided the apparent deficiencies without, in all likelihood, seriously sacrificing any of the past growth. Perhaps this is so; surely many economists of liberal persuasion would agree with the authors in this regard, and I do wonder if anything I could say here would convince them otherwise. Be that as it may, my reading of comparative development performance persuades me that such deficiencies are a generally inescapable transitional cost of the pronounced structural changes that typically accompany fastpaced growth. This is not in any way meant to deny their existence or to minimize their magnitude; nor is it meant to imply that Korea's performance could not have been better in at least some respects. But it is to argue that one should not gauge Korean performance against an unattainable ideal of complete allocative and managerial efficiency. ${ }^{2}$ Unless one believes that the transfer of technology can be costlessly undertaken and its complete assimilation immediately achieved, this

2. A considerable body of research employing frontier production functions shows that this ideal is not even achieved in the advanced countries-in all industries many firms use other than best-practice technologies. 
ideal is all the more implausible when applied to an economy that has been engaged in catching up to the global technological frontier.

There is surely no point in time over the past three decades for which a similarly conducted empirical investigation would not have uncovered deficiencies of comparable extent, magnitude, and seemingly probable cause. Thus a neoclassical reading of the authors' empirical findings effectively proves too much; that is, it does unless one is persuaded, as many analysts are not, that Korea's past development success occurred largely in spite of, rather than significantly because of, its government's interventionist practices. ${ }^{3}$ In short, such investigations cannot by themselves be legitimately used as the basis for arguing the necessity of "fundamental economic reform," which I take to mean reform that is systemic in the sense of radically changing the nature of the policy regime and the institutions that importantly guide resource allocation. To be compelling, the argument for so sweeping a change in development strategy requires the weight of vastly more evidence than is afforded by such an investigation, which is far more directly and immediately relevant to gauging the need for modest adjustments within the framework of an established development strategy.

But the authors do not simply focus on microeconomic departures from efficiency in stating their case for fundamental economic reform. They also importantly rely on the view that Korea has experienced disappointingly slow TFP growth insofar as factor accumulation has been the principal source of its growth. That they do so is particularly apparent in their introductory discussion, but the view is pervasive throughout their analysis. Has Korea's TFP growth performance in fact been disappointing? The answer, not surprisingly, depends on one's perspective. Considered comparatively, it can not fairly be termed at all disappointing. In the mainstream's consensus assessment, which reflects crosscountry estimates by Young and by Collins and Bosworth, Korea's TFP growth rate (whether aggregate or in manufacturing) over the 1960s through mid-1990s is seen to have been distinctly above the average in comparison to both developing and developed countries, but it is not seen to have been at all extraordinary or atypical. ${ }^{4}$ As they

3. The World Bank's (1993) report on the East Asian miracle is one of many studies that argues the efficacy of the government's practices; others, as shown by Wade (1994), find that the Bank's report seriously understates their contribution.

4. Young (1995); Collins and Bosworth (1996). Nelson and Pack (forthcoming) 
note, the authors' TFP growth estimates are broadly in line with this assessment. Accordingly, their view of disappointing performance cannot be considered consistent with the mainstream understanding of comparative TFP growth experience; Korea has distinctly not been an underachiever in terms of productivity growth relative to other countries. Their view is consistent, however, with the widespread and seemingly plausible expectation that developing countries have the potential to experience atypically rapid TFP growth.

This expectation flows from old notions of "economic backwardness'" a la Gershenkron as well as from contemporary growth theorizing. The central proposition is that developing countries can experience exceptional productivity performance by successfully exploiting the vast backlog of modern technology that is readily available for their use. But is there any evidence that this is in fact so? No, there is not, at least not insofar as one accepts the mainstream understanding of comparative TFP growth performance. In particular, the possibility of extraordinary TFP growth appears to be contradicted by the consensus view of East Asian experience. If, as in the mainstream perception, none of the East Asian "miracle economies"' has experienced exceptional productivity growth, then shouldn't this be taken as compelling evidence against its possibility? Where else is one to look for confirming evidence? Considering the contemporary period (from the end of World War II to the present), there are no other cases of similarly remarkable development success sustained over three and half decades.

There are two possible objections to the foregoing argument that the record of contemporary development experience contradicts the hypothesis positing the possibility of extraordinary TFP growth. One is that the mainstream's consensus assessment of comparative TFP growth performance is invalid; in particular, that it considerably understates the TFP growth that has been experienced by at least some of the East Asian economies. This is very probably so, but it is not pertinent to argue the contention in any detail here. Suffice it to say that my reading of the relevant literature has led me to the conclusion there are very strong reasons for being agnostic about our ability to comprehend sat-

argue that above-average TFP growth should in fact be seen as extraordinary because it was achieved in the context of an exceptionally rapid rate of capital accumulation. My argument later in these comments about the impossibility of extraordinary TFP growth given the mainstream appraisal complements rather than contradicts theirs. 
isfactorily the truth about comparative TFP growth experience; not only are the available data problematic and most likely inadequate, the tools of analysis are also probably insufficiently discriminating in important respects. ${ }^{5}$ As an agnostic in this matter, I have no particular reasons for not accepting, for the sake of argument, the mainstream perception. Moreover, the authors' analysis is clearly premised on this perception and can thus legitimately be appraised within it.

The other objection to the denial of the possibility of extraordinary TFP growth is that East Asian experience would not be pertinent if technological development in these economies could in any way be considered inadequate, such that they failed in attempting to realize the potential gains from technology transfer. But a careful reading of the reasonably extensive, albeit largely qualitative, body of research on technological development among developing countries leads one to exactly the opposite conclusion. ${ }^{6}$ Seen comparatively, the East Asian economies-Korea, Singapore, and Taiwan in particular-have been atypically very attentive to technological development and have pursued what appear in most respects to have been atypically very sensible approaches at the national as well as enterprise levels. Reasoning from the mainstream perception of comparative TFP growth performance, it would thus appear that exceptional productivity performance (at least in the contemporary world) is a chimera, comparable to the ideal of complete efficiency. Why might it be so; where is the flaw in reasoning leading to its expectation? It must lie in a mistaken view of the costs of technology transfer relative to its potential benefits. In fact, a reasonably large body of microempirical case study research does show that the costs are far from being trivial. ${ }^{7}$

To summarize the foregoing: Taken at face value and in light of the comparative record of development performance, the authors' evidence does not support their view that there is something fundamentally wrong with the Korean economic system. To see Korea's TFP growth performance as disappointing, or disappointingly slow, is to be inconsistent with the historical record, both comparatively and (within the mainstream perception) expectationally. In turn, where the authors prefer to

5. See Nelson and Pack (forthcoming) on the latter point.

6. See, for example, Hobday (1995) and Kim (1997) on East Asia in comparison with Lall (1987) on India.

7. Evenson and Westphal (1995). 
appraise the evidence from a particular set of ideas about the nature of successful development, it is consistent with the inadequate state of our understanding of the development process simply to take the evidence as providing rich documentation about certain aspects of arguably successful development. We lack a sufficient, empirically well-grounded theory of successful development from which to reach strong evaluative conclusions on the basis of a single set of observations. Embedded within this general critique is a narrower observation: the authors seriously underplay the many cases of remarkable microeconomic TFP performance that they have uncovered, giving them only rather begrudging acknowledgment. In this respect the authors appear to be far more attentive to the allocational deficiencies than to the productivity achievements that are surely no less at the heart of the development process.

The authors are highly circumspect in relating their empirical findings to the severe crisis that overtook Korea in 1997. Given their neoclassical predisposition, one should not doubt that they would have argued the necessity of fundamental economic reform even absent the crisis. One might wonder, though, if their argument would have been so forcefully expressed. But this is of lesser concern than the likelihood that some readers will believe that the crisis somehow confirms the authors' analysis. Such a conclusion would be doubly wrong. Insofar as the authors' findings pertain to underlying systemic problems in the operation of the Korean economy, they are not really relevant to understanding the nature of the crisis. In turn, as argued above, the evidence of such problems is not to be found simply in the authors' detailed appraisals of productivity performance, but rather in the full details of Korea's contemporary economic history. The authors' appraisals form but one small, yet nonetheless extremely valuable, contribution to the overall understanding of that history.

It is by now well appreciated that there was no single cause of the Korean crisis; analysts agree in recognizing multiple sources but differ in the relative weights that they attach to each. Nonetheless, most agree with the authors in assigning considerable importance to overinvestment as a proximate cause. ${ }^{8}$ But was excessive investment the result of systemic maladies; was it secular or cyclic in nature? While it is true that

8. See Chote (1998) and the references cited by the authors. 
Korean economic management at both the macroeconomic and enterprise levels has long been characterized by a bias toward excessive investment, the degree of overinvestment that was experienced in the several years prior to the crisis was highly aberrational. In the authors' most telling observation about the relationship of the crisis to overinvestment, they note that nearly half of Korea's total investment in semiconductors by the time of their study had been made since 1995 .

In the light of much other evidence (which the authors could very usefully have surveyed insofar as they chose to focus on the crisis) suggesting greatly excessive investment during this period relative to plausible estimates of demand growth in various sectors, one could well conclude that Korean economy was caught, as were many other East Asian economies, in a frenzy of manic investment behavior fueled by the hubris engendered by past success and global expectations of more to come. This is essentially correct; the crisis is best understood in terms of the periodic cycles of boom through fragility to bust that seem still to bedevil capitalist economies in their vigorous youth if not beyond. In short, there is nothing singularly unique about the Korean crisis that would tie it significantly to systemic problems in the economy's operation. The crisis was prototypically cyclical in nature; it was not the consequence of secular tendencies.

Nonetheless, the Korean economy has for some time been infected with systemic weaknesses that warranted resolute attention even though they remained largely benign. ${ }^{9}$ They were first manifested in Korea's big push to develop the so-called "heavy (largely metals and engineering-related) and chemical industries" in the mid-1970s, which led to an economic crisis spanning roughly 1979 to 1981 (Korea's only other post-1960 crisis of major proportions). Excessive, misdirected investment also played a major role in this earlier crisis, but with an important difference; the cause was largely the government's highly overt, interventionist direction of the investment. The crisis led to a serious effort of systemic reform in many areas that was at best only somewhat successful in accomplishing the stated objectives, which were entirely liberal in character. Even so, activist government intervention in the direction of investment was very greatly reduced. Continued recognition of the need for further reform effort in all

9. SaKong (1993) and Soon (1994) well state the case that this is so. 
of the initial areas resulted in a series of only partially successful reform undertakings that continued up to the present crisis.

What has made fundamental systemic revision so very difficult in the Korean setting is the critically consequential interaction between policy and institutional changes. This is well seen in the attempts to reform the highly problematic financial system and (not unrelated) chaebol structure of enterprise management and functioning. In both cases the central problem lies in the inability to generate appropriate institutional structures from those that already exist. Policy reform in the absence of radical institutional change can easily lead to severe difficulties; this is no better illustrated than by the other cause of the current crisis to which considerable importance has been generally assigned-the reckless short-term borrowing that was enabled by the relaxation of capital controls in an institutional setting of repressed financial development and insufficient prudential oversight. In short, institutional change is the essential element, one seemingly not easily achieved in the Korean context.

I am thus far less sanguine than are the authors that the liberal recipe for fundamental economic reform-however right it may be in terms of the proper direction, if not extent, of systemic change-can achieve the complete extension of the East Asian miracle in the Korean case. To put the same point another way: in watching for signs of the restoration of the Korean miracle, I will be far more attentive to institutional than to policy changes. Here is where the major contribution of the authors' empirical investigation is to be found. In highlighting Korea's deficiencies in the transfer of "managerial knowledge," the authors have identified and given meaningful substance to a multidimensional institutional failing of obviously great importance in gauging Korea's strategic needs. Although they do not draw particular attention to it in their summary discussions, the authors have also documented serious problems of a more general nature in the areas of labor management and labor relations, which equally merit strategic attention. Finally, the authors' investigation importantly identifies Korea's services sector as being an area to which considerable investment should be directed. Whatever the changes finally made in Korea's development strategy, they should surely address these elements uncovered by the authors' diagnosis of the deficiencies of Korea's precrisis development strategy. 
Authors' Response: Both Bosworth and Westphal are skeptical of the role low returns to capital played in the recent crisis in Korea, noting that returns on average were comparable to those in other OECD countries. Our paper, however, highlights several large manufacturing industries that had high capital intensities and low returns. These were the industries that were borrowing (directly or through intermediaries) from abroad. We recognize that many factors contributed to the crisis and argue simply that poor investment decisions made Korea more vulnerable to crisis. Bosworth objects to the use of the concept of capital productivity. The ratio of output to capital is a standard one, reported routinely by the Bureau of Labor Statistics for the United States (see the bureau's Web site). It can be misunderstood, as indeed can the concept of labor productivity, but it can also be useful, particularly in understanding returns to capital. Westphal takes issue with our implication that total factor productivity growth in Korea could have been faster, even though it was already well above average for a developing country. We acknowledge fully in the paper that Korea has performed better than most developing countries. An advantage of our detailed case studies, however, is in allowing us to see where Korean industries have had problems and where a new policy environment might alleviate those problems. Whether this environment is interventionist or liberal is much less important than the need for a shift in focus-away from promoting rapid investment concentrated in specific sectors and toward encouraging productivity growth and broader-based investment.

\section{Commentators' References}

Chote, Robert. 1998. "Financial Crises: The Lessons of Asia." In Financial Crises and Asia, CEPR Conference Report 6, 1-34. London: Center for Economic Policy Research.

$\rightarrow$ Collins, Susan M., and Barry P. Bosworth. 1996. "Economic Growth in East Asia: Accumulation versus Assimilation." Brookings Papers on Economic Activity 2: 135-91.

Evenson, Robert E., and Larry E. Westphal. 1995. “Technological Change and Technology Strategy." In Handbook of Development Economics, edited by Jere Behrman and T. N. Srinivasan, 3A, 2209-99. Amsterdam: North Holland.

Hobday, Mike. 1995. Innovation in East Asia: The Challenge to Japan. Brookfield, Vt.: Edward Elgar. 
Kim, Linsu. 1997. Imitation to Innovation: The Dynamics of Korea's Technological Learning. Boston: Harvard Business School Press.

Lall, Sanjaya. 1987. Learning to Industrialize: The Acquisition of Technological Capability in India. Macmillan.

Nelson, Richard R., and Howard Pack. Forthcoming. "The Asian Growth Miracle and Modern Growth Theory." Economic Journal.

SaKong, Il. 1993. Korea in the World Economy. Washington, D.C.: Institute for International Economics.

Soon, Cho. 1994. The Dynamics of Korean Economic Development. Washington, D.C.: Institute for International Economics.

Wade, Robert. 1994. "Selective Industrial Policies in East Asia: Is the East Asian Miracle Right?' In Miracle or Design? Lessons from the East Asian Experience, edited by Albert Fishlow and others, 55-79. Policy Essay 11. Washington, D.C.: Overseas Development Council.

World Bank. 1993. The East Asian Miracle: Economic Growth and Public Policy. Oxford University Press.

$\rightarrow$ Young, Alwyn. 1995. "The Tyranny of Numbers: Confronting the Statistical Realities of East Asian Growth Experience." Quarterly Journal of Economics 110 (August): 641-80. 